\title{
SOBERANÍA ESTATAL, SUPREMACÍA CONSTITUCIONAL E INTEGRACIÓN EUROPEA A LA LUZ DE LA JURISPRUDENCIA DEL TRIBUNAL
CONSTITUCIONAL FEDERAL ALEMÁN
}

Benito Aláez Corral

Catedrático de Derecho Constitucional

Universidad de Oviedo

\begin{abstract}
SUMARIO
I. Estatalidad, competencia sobre las competencias e identidad constitucional democrática como grandes argumentos del Tribunal Constitucional Federal alemán para limitar el proceso de integración europea.

II. La soberanía jurídicamente entendida: la competencia sobre las competencias y su posible ubicación en la Constitución nacional..

III. Las dos facetas de la competencia sobre las competencias como contenido normativo de la soberanía.

IV. Conclusión: Necesarios pero defectuosos intentos de la jurisdicción constitucional nacional para garantizar la supremacía constitucional en el proceso de integración europea
\end{abstract}

\section{ESTATALIDAD, COMPETENCIA SOBRE LAS COMPETENCIAS E IDENTIDAD CONSTITUCIONAL DEMOCRÁTICA COMO GRANDES ARGUMENTOS DEL TRIBUNAL CONSTITUCIONAL FEDERAL ALEMÁN PARA LIMITAR EL PROCESO DE INTEGRACIÓN EUROPEA}

En este trabajo se pretende reflexionar una vez más ${ }^{1}$ sobre la tensa relación que se establece entre el dogma de la supremacía de las constituciones nacionales y el proceso de

1 Son muchos los trabajos existentes en nuestro país sobre los límites constitucionales al proceso de integración europea y específicamente, desde una perspectiva jurídico-constitucional, sobre el conflicto entre la su- 
integración europea tomando para ello como pretexto la jurisprudencia del Tribunal Constitucional Federal alemán (en adelante BVerfG —-Bundesverfassungsgericht-) sobre el control de constitucionalidad del proceso de integración europea ${ }^{2}$, una de cuyas últimas referencias más importantes se encuentra en la Sentencia de 30 de septiembre de 2009 (comúnmente denominada Sentencia Lisboa) ${ }^{3}$.

Toda esta jurisprudencia alemana, desde la primera decisión Solange I de $1974^{4}$ hasta la recentísima decisión sobre el Pacto para la creación de un fondo europeo de rescate de $2012^{5}$ pone de relieve la tensión existente entre la aspiración política de continuar el proceso de integración europea y la afirmación (más o menos jurídica) de la identidad constitucional de los Estados miembros. Ello se debe a que, a pesar de que en la resolución de esta tensión el BVerfG trata de recordar los límites jurídico-constitucionales internos de los Estados miembros que vinculan tanto a los órganos nacionales como a las instituciones europeas en la adopción de las decisiones políticas que guían este proceso de integración, al definir esos límites, sin embargo, incurre, como se verá, en una confusión entre lo políticamente posible/deseable y lo jurídicamente prescrito respecto de ellos, por lo que su intento de reafirmación de la supremacía de la Constitución termina siendo defectuoso.

Ahora bien, aún con defectos, lo que no parece de recibo es valorar la congruencia o incongruencia de la postura del Estado alemán respecto de la integración europea comparando la posición del Gobierno alemán en el Consejo o en los acuerdos intergubernamentales con la postura del BVerfG en esta larga jurisprudencia de control, so pena de confundir nuevamente política y derecho. Las exigencias políticas del Gobierno alemán utilizando el marco jurídico comunitario para erosionar las competencias políticas de los Estados miembros con graves problemas económicos pueden tener en estos Estados una respuesta igualmente política de parte de sus Gobiernos, pero también deberían tener una respuesta jurídica adecuada desde sus instituciones jurisdiccionales (desde el Tribunal Constitucional español, por ejemplo) ${ }^{6}$. Y dichas exigencias no se pueden confundir con los condicionantes constitucionales que — con una interpretación discutible de la Grundgesetz, pero en todo caso desde la argumentación jurídica- establece el BVerfG respecto del proceso de construcción europea, especialmente en la Sentencia Lisboa.

Desde los años setenta hasta la actualidad los condicionantes constitucionales que el BVerfG ha impuesto al proceso de integración europea han girado expresa o implícitamente entorno a tres grandes argumentos, que se explicitan de forma palmaria en la Sen-

premacía/soberanía de la Constitución estatal y los avances en dicho proceso de integración. Permítaseme referirme a uno de los últimos de PUNSET BLANCO, R., Soberanía estatal e integración europea, Asamblea, $\mathrm{n}^{\circ}$ 25, 2011, págs. 145 ss.; y a uno de los primeros Aláez Corral, B., Soberanía constitucional e integración europea, Fundamentos, Vol. I, 1998, págs. 503 ss.

$2 \mathrm{Al}$ respecto de esta jurisprudencia como una de las más importantes para afrontar las encrucijadas a las que se enfrenta el Estado alemán en el cambio de milenio, véase ALÁEZ CORRAL/ÁLVAREZ ÁLVAREZ, Las decisiones básicas del Tribunal Constitucional Federal alemán en las encrucijadas del cambio de milenio, CEPC, 2008.

3 BVerfGE 123, 267 ss.

4 BVerfGE 37, 271 ss.

5 BVerfG, 2 BvE 4/11 de 19 de junio de 2012.

6 Oportunidad para establecer esas exigencias que perdió el Tribunal Constitucional español cuando inadmitió a trámite el recurso de amparo de IU contra el modo de tramitar la reforma constitucional del Art. $135 \mathrm{CE}$. 
tencia Lisboa de 2009 (aunque se fueran desgranando desde la primera Sentencia Solange I): el primero se refiere al respeto a la caracterización de Alemania como un Estado soberano (su estatalidad); a ello vinculado estaría el respeto a su identidad constitucional, que en el caso de Alemania, se identifica con el núcleo constitucional intangible del Art. 79.III GG ${ }^{7}$; y finalmente y también como concreción de dicha identidad constitucional, aparece el límite del respeto al principio democrático tal y como está configurado en la Grundgesetz alemana ${ }^{8}$ y, en particular, del núcleo esencial de los derechos fundamentales reconocidos en ella ${ }^{9}$. Estos tres elementos se pueden vincular entre sí de la siguiente forma: la participación Alemania en la Unión Europea ni ha disuelto ni podría disolver la estatalidad de Alemania (esto valdría para cualquier Estado miembro), puesto que ni la UE es un Estado federal, ni la transferencia de poderes soberanos a ésta puede desconocer que el origen de la Unión es un Tratado internacional y que los Estados continúan siendo los «Señores de los Tratados» ${ }^{10}$ y no actúan como poderes integrados en un proceso constituyente europeo. Como consecuencia de ello, la Unión debe respetar la identidad constitucional de los Estados miembros, no solo porque así se ha previsto en el TUE (Art. 4.2), sino porque así lo exige la Grundgesetz alemana que impone al mismísimo poder de reforma constitucional el límite absoluto del respeto a los principios identificadores de la Constitución (Art. 79.III GG), límite al que también está sujeto el legislador de reforma constitucional que autoriza la ratificación de los Tratados fundacionales de la Unión o sus modificaciones. Precisamente porque se trata de una identidad constitucional nacional, y en el caso de Alemania el principio democrático es esencial y parte esencial de ésta, es por lo que, finalmente, dicho principio democrático, y sus elementos característicos (como los Derechos Fundamentales), tal y como son garantizados por la Constitución alemana, deben ser respetados por los poderes constituidos alemanes pero también por los poderes constituidos europeos, residiendo en el BVerfG el poder último de control de dicho respeto, en tanto garante de que la competencia sobre las competencias permanece en manos alemanas.

Se podrá discutir lo oportuno de realizar semejantes aseveraciones en el texto de sentencias que, con todo, terminan afirmando la constitucionalidad del proceso de integración europea alcanzado hasta ahora, o incluso lo acertado en clave constitucional interna de la concreta extensión dada a los tres argumentos que el BVerfG esgrime como límites al proceso de integración, pero lo cierto es que, salvo que se afirme la transferencia a la Unión Europea de la competencia sobre las competencias y la consiguiente disolución de la supremacía jurídica de la Constitución nacional ${ }^{11}$, la función de salvaguardia de dicha Constitución nacional es un deber de los Tribunales Constitucionales. Hacerlo tiene, además, la virtud académica de reabrir el debate sobre los conceptos clave de la Teoría constitucional y del Estado, como los de estatalidad, soberanía, identidad constitucional o principio democrático ${ }^{12}$, y, en especial, pone el dedo en la llaga de la confusión entre lo

7 Véanse la Sentencia Maastricht, BVerfGE 89, 155, 182 ss., y la Sentencia Lisboa BVerfGE 123, 267, 340 ss

8 Véanse la Sentencia Maastricht, BVerfGE 89, 155, 182 ss., y la Sentencia Lisboa BVerfGE 123, 267, 340 ss

9 Tal y como se exige desde la Sentencia Solange I, BVerfGE 37, 271, 279.

10 Expresión acuñada por primera vez en la Sentencia Maastricht: BVerfGE 89, 155 ss.

11 Por Constitución nacional se entiende aquí la Constitución del Estado-nación soberano.

12 De excesivamente doctrinal califica, por ejemplo, HÄBERLE, P. La regresiva «sentencia Lisboa» como «Maastricht-II» anquilosada, ReDCE. n 12, 2009, págs. 403-404. 
políticamente deseable y lo jurídicamente lícito, que muchos ya creíamos superada con la diferenciación funcional de los sistemas de la Política y el Derecho ${ }^{13}$.

En efecto, como se verá seguidamente, cuando se critica la inadaptación del BVerfG a la evolución del concepto de soberanía como consecuencia de la globalización, se obvia, que ésta no se ha producido en iguales términos en los subsistemas sociales de la Economía, la Política o el Derecho. Sin previamente afirmar la existencia (en el sentido de la validez) de un ordenamiento jurídico global, sea universal sea europeo, que se superponga a los Estados miembros, difícilmente se puede atribuir esta crítica a la jurisprudencia del BVerfG sin, al hacerlo, mezclar los planos de la Política y el Derecho. Del mismo modo, aún debiendo tenerse en cuenta que el principio democrático no se realiza únicamente en términos nacionales (cosa que no siempre reconoce la jurisprudencia del BVerfG por una metapositiva concepción nacionalista de la soberanía popular y de la democracia), no cabe reprochárselo al BVerfG, sin, al hacerlo, confundir la pretensión política (futura) de europeizar la esencia del principio democrático con obligación jurídica (presente) de europeizar solo una parte de la realización de ese principio, pero preservar su esencia en manos del Pueblo nacional mientras éste no se desposea democráticamente de su capacidad constitucional de legitimación del poder público.

Para intentar clarificar estas cuestiones que plantea la jurisprudencia del BVerfG en su control de constitucionalidad del proceso de integración europea procederé a continuación a analizar con un poco más de detalle tanto el presupuesto como las consecuencias de la tesis que defiende. A saber: de un lado, solo es posible un análisis jurídico-constitucional de la cuestión, es decir, que indague en el fundamento último de la solución jurídica del potencial conflicto entre la Constitución nacional y el Derecho (originario o derivado) de la Unión europea, si se parte (presupuesto) de un entendimiento abstracto de la soberanía como cualidad de un único ordenamiento jurídico, concebido como un todo (monismo ordinamental) que debe aún fundamentarse en la Constitución nacional conforme al modelo de relación internormativa que ésta haya establecido, y que en el caso de la Grundgesetz alemana es el de la supremacía de una supra-constitución material intangible. De otro lado, mientras esa unidad deba construirse total o parcialmente (en su núcleo esencial) desde la perspectiva del ordenamiento nacional, de modo que la competencia sobre las competencias (expresión normativa de la soberanía) permanezca en manos de los Estados miembros que preservan esa identidad constitucional intangible, parece inevitable que sea, cual se la extensión de su poder de control y sea cual sea la extensión del parámetro, siga en manos del órgano jurisdiccional garante de la Constitución nacional, el BVerfG en el caso de Alemania, dicha competencia de control de constitucionalidad del proceso de integración europea (consecuencia).

El análisis será dogmático-constitucional y se realizará en perspectiva comparada con respecto sobre todo a la jurisprudencia de nuestro Tribunal Constitucional, pero también a lo dicho por el Conseil Constitutionnel francés, la Corte Costituzionale italiana o el Tribunal Constitucional checo, por citar algunos, tratando de poner de relieve cómo se en-

13 Sobre la diferenciación funcional del sistema jurídico, cfr. LUHMANN, N., Die Ausdifferenzierung des Rechts, Subrkamp, Frankfurt a.M., 1981. y aplicado a nuestro ordenamiento ALÁEZ CORRAL, B., Los límites materiales a la reforma de la Constitución española de 1978, CEPC, Madrid, 2000, págs. 98-99 ss. 
tremezclan los planos de la Política y el Derecho, lo cual lleva a un uso confuso de los conceptos de soberanía y estatalidad, pero también de Constitución o democracia.

\section{LA SOBERANÍA JURÍDICAMENTE ENTENDIDA: LA COMPETENCIA SOBRE LAS COMPETENCIAS Y SU POSIBLE UBICACIÓN EN LA CONSTITUCIÓN NACIONAL}

\section{El CONTENido INALIENABle DE LA SOBERANÍA: LA COMPETENCIA SOBRE LAS COMPETENCIAS}

Los pasos dados en el proceso de integración europea desde el Tratado de Maastricht plantean, por las implicaciones cuantitativas y cualitativas de la traslación de soberanía que implican, el problema relativo a si la pérdida de soberanía ha ido más allá de lo jurídico-constitucionalmente admisible, sea por infracción de exigencias procedimentales sea por traspaso de líneas rojas materiales de la soberanía estatal. Se trata de una cuestión que, ciertamente, no es nueva, pues ya se planteaba en relación con el derecho comunitario, tal y como hoy lo conocemos, y que no tiene que ver solo con la traslación de concretas nuevas competencias a la Unión sino también, y sobre todo, con la reafirmación primacía de las normas de la Unión sobre las normas estatales y la consiguiente competencia jurisdiccional exclusiva para juzgar si dicha primacía debe operar o no ${ }^{14}$. El principio de primacía del derecho de la Unión Europea, afirmado por el TJUE también con respecto a las normas constitucionales de los Estados miembros ${ }^{15}$, pero cuestionado por el Tribunal Supremo para Inglaterra y Gales ${ }^{16}$ y por algunos Tribunales Constitucionales como el alemán, el italiano, el francés, el checo, el polaco o el español ${ }^{17}$, viene a representar el embrión de la constitucionalización de la construcción europea y una amenaza para la supremacía de las Constituciones de los Estados miembros, auténtico alma mater

14 De las tres posibles opciones ante el conflicto de supremacías que plantea FERRERES COMELLA, V., La Constitución española ante la cláusula de primacía del Derecho de la Unión Europea. Un comentario a la Declaración 1/2004 del Tribunal Constitucional, en LÓPEZ CASTILLO/SÁIZ ARNÁIZ/FERRERES COMELLA, Constitución española y Constitución europea Análisis de la Declaración del Tribunal Constitucional (DTC 1/2004, de 13 de diciembre), CEPC, Madrid, 2005, págs. 77-78: aceptar que estamos ante un conflicto irreductible; aceptar que existe un conflicto, y tratar de reducir la tensión entre los principios en colisión a través de un reajuste de sus contenidos respectivos; $y$, por último, negar que existe un conflicto, optamos por la primera, pues creemos que no se debe ni se puede prescindir del plano de la validez en la relación internormativa y en éste el conflicto solo puede solucionarse sobre la base de la afirmación de la supremacía de la Constitución nacional o la supremacía del Derecho de la Unión.

15 STJUE 6/64, de 15 de julio de 1964, caso Costa/ENEL.

16 Sentencia de la Corte Suprema para Inglaterra y Gales, Caso Thoburn v. Sunderland city council, de 18 de febrero de 2002, [2002] EWHC 195 Admin, párr. 69-70,

17 Sentencia n ${ }^{\circ} 232$ de 1989 de la Corte Costituzionale italiana, Decisión del Conseil Constitutionnel francés 97-394 de 31.12.1997, Sentencia Lisboa del BVerfG alemán de 2009, BVerfGE 123, 267, 349-353, de 30 de junio de 2009 (ya en la Sentencia Maastricht de 1992, BVerfGE 89, 155, 187ss.), Sentencia del Tribunal Constitucional checo (19/2008), de 26 de noviembre de 2008 sobre el Tratado de Lisboa, párr. 130-132; Sentencia del Tribunal Constitucional polaco (K32/09), de 24 de noviembre de 2012, sobre el Tratado de Lisboa, FJ III.1.3; DTC 1/1992, de 1 de julio, F.J, $4^{\circ}$ y DTC $1 / 2004$, de 13 de diciembre, FJ $4^{\circ}$. 
de la soberanía estatal. Incluso aunque se entienda como primacía meramente aplicativa y no como supremacía respecto de la validez ${ }^{18}$, los potenciales conflictos no desaparecerían sino que únicamente se postergarían al momento en que el guardián de la Constitución nacional pretendiese hacer valer los condicionamientos constitucionales del principio de primacía del derecho europeo ${ }^{19}$, que es precisamente lo que ha puesto sobre la mesa el Bundesverfassungsgericht alemán sobre todo en sus sentencias Maastricht y Lisboa.

Solo la conversión de los Tratados de la Unión en una auténtica Constitución, entendida como norma suprema de un ordenamiento complejo en la que se concentrase la Kompetenz-Kompetenz, constituiría, pues, la expresión indubitada del proceso de disolución de la soberanía estatal que, al amparo de la mencionada jurisprudencia del TJUE, habría venido operando silenciosamente por lo menos desde la entrada en vigor del TUE. Un intento parcial y fallido de ello fue el non nato Tratado Constitucional de Roma de 2004 que, refrendando el criterio del TJUE, además de prever en su texto la primacía del derecho de la Unión sobre el derecho estatal, configuraba dicha Constitución al modo y manera tradicional de los documentos constitucionales, la dotaba de rigidez orgánica en su modificación (Arts. IV 443-445) ${ }^{20}$, y exigía trámites consensuados en el proceso de secesión de cualquier Estado miembro (Art. I-60)². Pero, desde la perspectiva de los Tribunales constitucionales alemán, checo polaco o español, por citar algunos, esta traslación de una competencia sobre las competencias a la Unión aún no se ha producido ${ }^{22}$.

Así expuesto el problema, ya nos pone sobre la pista de que tanto en la doctrina mayoritaria como en parte también en la propia jurisprudencia constitucional alemana, la cues-

18 Tal y como pretende el Tribunal Constitucional español en la DTC 1/2004, de 13 de diciembre, FJ $4^{\circ}$.

19 Cfr. RODRÍGUEZ-IZQUIERDO SERRANO, M., Primacía y subsidiariedad en la Unión Europea, CEPC, Madrid, 2011, págs. 190 ss.

20 Procedimientos ordinario y simplificado de revisión en el que se incluían las denominadas «cláusulas pasarela» que permitían, por decisión unánime del Consejo y mayoritaria del parlamento Europeo, modificar los Tratados sustituyendo la unanimidad por mayoría cualificada en la toma de algunas decisiones; cláusulas que han pasado con matices al vigente Art. 48 TUE y que el BVerfG considera en la Sentencia Lisboa, BVerfGE, 123, 267, 387-393, constitucionalmente lícitas y aplicables sin necesidad de una nueva Ley de autorización (en el caso de las especiales que versan sobre materias que ya son competencia de la Unión) siempre que el Parlamento alemán haya autorizado al Gobierno federal a prestar su consentimiento en obligarse dentro del Consejo Europeo.

21 El apartado segundo del Art. I-60 establecía que «el Estado miembro que decida retirarse notificará su intención al Consejo Europeo. A la luz de las orientaciones del Consejo Europeo, la Unión negociará y celebrará con ese Estado un acuerdo que establecerá la forma de su retirada, teniendo en cuenta el marco de sus relaciones futuras con la Unión. Este acuerdo se negociará de conformidad con el apartado 3 del artículo 325. El Consejo lo celebrará en nombre de la Unión por mayoría cualificada, previa aprobación del Parlamento Europeo». Para el caso de que dicha retirada consensuada no fuese posible, el apartado tercero del mismo artículo preveía que la Constitución dejará de aplicarse al Estado de que se trate a partir de la fecha de entrada en vigor del acuerdo de retirada o, en su defecto, a los dos años de la notificación a que se refiere el apartado 2 , salvo si el Consejo Europeo, de acuerdo con dicho Estado, decide por unanimidad prorrogar dicho plazo.

22 BVerfGE 123, 267, 349-353 (ya en la BVerfGE 89, 155, 187ss.); DTC 1/1992, de 1 de julio FJ 4º; DTC 1/2004, de 1 de noviembre, FJ 4º; Sentencia del Tribunal Constitucional polaco (K32/09), de 24 de noviembre de 2012, sobre el Tratado de Lisboa, FJ III.2; y Sentencia del Tribunal Constitucional checo de 19/2008, de 26 de noviembre de 2008 sobre el tratado de Lisboa, párr. 130-132. Sobre esta última véase Nemeckova, P., La Sentencia del Tribunal Constitucional Checo de 26.11.2008 sobre la compatibilidad del Tratado de Lisboa con la Constitución de la República Checa, Revista de Derecho Comunitario Europeo, n 32, 2009, pág. 247. 
tión del conflicto entre las Constituciones de los Estados miembros y el Derecho de la Unión europea está mal resuelta en buena medida porque se plantea desde un erróneo entendimiento político-material de la soberanía estatal, que la identifica, siguiendo la teoría política clásica que llega hasta el siglo XIX, con un poder único, indivisible e inalienable que descansa en un sujeto que personifica al Estado. Ciertamente este entendimiento se adecua mal a la evolución que ha experimentado el Estado sobre todo en los últimos setenta y cinco años, a las exigencias de un mundo en el que los sistemas sociales que rodean al jurídico (como el económico) se han globalizado y en el que la complejidad social, también en el ámbito jurídico, se ha incrementado enormemente, por ejemplo con la transferencia de poder político a instituciones supranacionales como la Unión Europea. De ahí que una concepción de la soberanía que la identifica con una cualidad del Estado o de un sujeto en que éste se halla personificado y cuyo contenido es mensurable en términos político-cuantitativos o cualitativos, como pretende el $\mathrm{BVerfG}^{23}$, sea criticable desde muchos puntos de vista, incluida la concepción nacionalista del principio democrático en que se sustenta, y sea inconsistente con el grado de descentralización del poder político que ya se ha alcanzado el proceso de integración europea en ámbitos financiero-económicos ${ }^{24}$ :

Pero la solución tampoco pasa por la sustitución de este entendimiento político-estatalista de la soberanía por un concepto igualmente político pero europeísta, en el que, partiendo de ese mismo entendimiento de la soberanía como conjunto de poderes públicos, todos de igual valor normativo, ésta se comparte entre los Estados miembros y la Unión Europea, al menos durante este interim de formación de un Estado federal europeo $^{25}$, pudiendo las instancias jurisdiccionales supremas de unos y otros ordenamientos autónomos afirmar legítimamente su competencia para juzgar la licitud del ejercicio de las competencias de la Unión y de los Estados miembros respectivamente ${ }^{26}$, o debiendo abstenerse de dicho enjuiciamiento de los conflictos interordinamentales en tanto cuestión política que debe quedar en manos de los Parlamentos ${ }^{27}$. Lo anterior conduciría a que posibles y contradictorias interpretaciones del alcance de la atribución competencial se deban clarificar extrajurídicamente por la vía política de $\operatorname{los}_{\text {hechos }}{ }^{28}$, o a una debili-

23 Véase la BVerfGE 123, 267, 357-358, donde expresamente se establece que el principio democrático vigente en el sistema constitucional alemán exige la preservación de la soberanía alemana, en el sentido abierto a la integración europea y al derecho internacional que prevé la Grundgesetz, para lo cual no puede suceder que « en los Estados miembros no permanezca un espacio suficiente de autodeterminación política de las condiciones de vida económicas, culturales y sociales».

24 Como pone de relieve acertadamente la crítica de MENÉNDEZ, A., La unión Europea en el espejo de Lisboa, en Vidal Prado (Coord.) La sentencia del Lisboa del Tribunal Constitucional Federal alemán, CEPC, Madrid, 2011, págs. 129-135.

25 Cfr. la crítica al concepto de soberanía manejado por el BVerfG en a Sentencia Lisboa de Häberle, P., La regresiva "sentencia Lisboa» como «Maastricht-II» anquilosada, ob. cit., págs. 416-418.; o la de MARTÍN Y PÉREZ DE NANCLARES, J.M., Órdago del Tribunal Constitucional Federal alemán al proceso de integración europea (algo más que una sentencia crítica con el Tratado de Lisboa), REAF, nº 13, 2011, págs. 109 ss.

26 Como parece desprenderse de la posición de DÍEZ-PICAZO GIMÉNEZ, L. M., La naturaleza de la Unión Europea, InDret, no 4, 2008, págs. 26-38.

27 Como sugiere MENÉNDEZ, A., La unión Europea en el espejo de Lisboa, ob. cit., págs. 161-163.

28 Como pone de relieve la Sentencia del TJUE Tanja Kreil v. Bundesrepublik Deutschland (asunto C285/98), de 11 de enero de 2000, en la que se declara la aplicación prevalente de la Directiva 76/207/CEE, de 9 de febrero de 1976, relativa al principio de igualdad de trato entre hombres y mujeres en lo que se refiere al acceso al empleo, a la formación y a la promoción profesionales y a las condiciones de trabajo sobre el Art. 
tación de la eficacia normativa de la Constitución como norma suprema de difícil compatibilización con las cláusulas de supremacía insertas en los textos constitucionales y con los mecanismos de control de constitucionalidad previstos, y en todo caso inadmisible sin una expresa desposesión de esa supremacía por los cauces constitucionalmente previstos de la reforma constitucional o del ejercicio del poder constituyente ${ }^{29}$.

Ni uno ni otro entendimiento político-material de la soberanía, por muy rígido e impracticable el estatalista, y por demasiado práctico y jurídicamente evanescente el europeísta, responden a una realidad jurídica en la que los Estados miembros siguen fundamentándose en unas normas (Constituciones o normas de reconocimiento) que pretenden una absoluta supremacía en la validez, sobre todo por ser la expresión democrática del poder constituyente del pueblo, y en la que simultáneamente la Unión Europea, fundamentada en los Tratados de la Unión ${ }^{30}$ — que no dejan de ser Tratados internacionales-, pretende afirmar a través de su TJUE también una absoluta primacía aplicativa en el ámbito de las competencias transferidas que resulta excluyente de aquella supremacía constitucional en la validez.

Por ello sigue resultando más necesaria que nunca una comprensión jurídica y no política de la soberanía, que la identifique con una cualidad del ordenamiento jurídico, no con una cualidad de un sujeto ${ }^{3}$, y que la vincule a expresar la capacidad autorreferente e ilimitada de fundamentación y reconocimiento de la propia validez del ordenamiento jurídico, es decir, a la competencia sobre las competencias para decidir su propia existencia ${ }^{32}$.

\section{2. ¿MONISMO O PLURALISMO ORDINAMENTAL?}

Este análisis jurídico de la soberanía y de la interrelación entre subordenamientos jurídicos exige, a su vez, saber en cuál de ellos se puede residenciar aquella cualidad de la soberanía y si es posible residenciarla en varios ordenamientos al mismo tiempo sin que las condiciones de existencia de éstos se vean alteradas, es decir, habría sido preciso que el TJUE y los Tribunales constituciones de los Estados miembros, y en especial el BVerfG, se hubiesen pronunciado, desde un entendimiento jurídico abstracto de la soberanía, sobre si existe un único ordenamiento jurídico del que forman parte los demás, aunque dotados de autonomía, o diversos ordenamientos jurídicos con posibles existen-

12a)IV GG, pero dicha posibilidad de incorporación de la mujer al ejército alemán en puestos que impliquen el uso de armas de fuego solo es posible a partir del la entrada en vigor de la Ley de reforma constitucional de 19 de diciembre de 2000, es decir, casi un año después de la resolución de la cuestión prejudicial por el TJUE.

29 En el caso de Alemania la Sentencia Lisboa, BVerfGE 123, 267, 343, deja abierta la cuestión de si siquiera el poder constituyente originario del pueblo alemán, ejercido en virtud del Art. 146 GG, podría disolver la soberanía estatal de Alemania en un Estado federal europeo o si, por el contrario, la garantía de la identidad constitucional alemana del Art. 79.III GG también le vincula.

30 El TUE, el TFCE y la Carta de DDFF de la Unión Europea.

31 KELSEN, H., Das Problem der Souveränität und die Theorie des Völkerrrechts, Scientia, Aalen, 1960 (reimpresión de la edición de 1928), págs. 36 y 40.

32 En un sentido parecido, HILLGRUBER, C., Soberanía - La defensa de un concepto jurídico, InDret, $\mathrm{n}^{\circ}$ 1, 2009, pág. 12. y GRIMM, D. Souveränität: Herkunft und Zukunft eines Begriffs, Berlin University Press, Berlín, 2009. págs. 99 ss. En contra notablemente HÄBERLE, P., La regresiva «Sentencia Lisboa» como «Mastricht-II» anquilosada, ob. cit., págs. 417-418. 
cias soberanas simultáneas. Solo desentrañando previamente esta cuestión de si el sistema jurídico puede ser concebido desde la perspectiva de su validez como un todo único (posiciones monistas) o si, por el contrario, debe partirse de la existencia de una pluralidad de ordenamientos coexistentes simultáneamente e independientes en la fundamentación de su validez (posiciones pluralistas), se podrá dar adecuada respuesta jurídica a la cuestión de cuáles son los criterios que han de regir las relaciones de conflicto entre el ordenamiento estatal y el derecho internacional, con inclusión del derecho comunitario europeo.

La paulatina deriva histórica de diferenciación estructural y funcional del sistema jurídico es tan clara, a mi juicio, desde la aparición del moderno Estado-nación, que solo desde una posición monista se puede describir la pretensión del sistema jurídico (sea cual sea su cúspide) de existir como un sistema autorreferente y positivo, partiendo de la premisa epistemológica de que solo hay sistema jurídico allí donde se regula directa o indirectamente el uso de la coacción física para garantizar expectativas contrafácticamente, no el uso de otras formas de coacción como la moral, la económica, o la política ${ }^{33}$.

En efecto, desde posiciones pluralistas ${ }^{34}$ de diferenciación de los ámbitos de validez del ordenamiento estatal y el ordenamiento comunitario, no es posible dar una respuesta única y coherente a la confrontación que puede surgir entre distintos ordenamientos, como no sea la del mantenimiento objetivo de dicha confrontación ${ }^{35}$. Todo lo más, estas posiciones dogmáticas conciben las relaciones interordinamentales desde el plano de la aplicabilidad de las normas, como sucedía en los ordenamientos premodernos, y las construyen sobre la base de la primacía aplicativa y no de la supremacía en el fundamento de valide $^{36}$. Salvando las distancias con el pluralismo jurídico existente en la época premoderna, mantener este pluralismo actualmente cuestiona, igual que entonces, la autorreferencialidad de los sistemas jurídicos (y su legitimación democrática allí donde la creación normativa se ha estructurado democráticamente), en la medida en que hace depender su existencia positiva de un grado de cumplimiento fáctico que ninguno de los ordenamientos en conflicto puede garantizar por sí mismo, ni el ordenamiento de la Unión Europea a través de la coacción económica, única de que dispone, ni los ordenamientos de los Estados miembros con la coacción física.

Por ello, se hace necesaria una respuesta desde posiciones monistas que determine la posición de las normas estatales en el ordenamiento comunitario o, a la inversa, de las nor-

33 Sobre estas características diferenciadoras del sistema jurídico respecto de otros sistemas de comunicación social, véase ALÁEZ CORRAL, B. Los límites materiales a la reforma de la Constitución española de 1978, ob. cit., págs. 98-99.

34 Véase una formulación clásica del dualismo derecho nacional-derecho internacional en TRIEPEL, H. Völkerrecht und Landesrecht, Scientia Antiquariat, Aalen, 1958(reimpresión de la edición de1899), págs. 9, 11 ss., 27 ss.

35 Cfr. KELSEN, H., Das Problem der Souveränität und die Theorie des Völkerrechts, ob, cit., pág. 120-121 ss. En el sentido de que no es posible encontrar una respuesta científicamente satisfactoria a este problema, por lo que la confrontación es ineludible, cfr. MACCORMICK, N., La sentencia de Maastricht: soberanía ahora, Debats, n 5, 1996, pág. 29; y tratando de solventar el problema en términos de aplicabilidad y no de validez, con lo que se elude la jerarquización de los ordenamientos, cfr. REQUEJO PAGÉS, J. L., Las normas preconstitucionales y el mito del poder constituyente, CEPC, Madrid, 1998, págs. 109 y ss.

36 Es el caso de la jurisprudencia del TJUE sobre la primacía del derecho comunitario desde la STJCE 6/64, de 15 de julio de 1964, caso Costa/ENEL. 
mas comunitarias en el ordenamiento estatal ${ }^{37}$. En efecto, dicho monismo puede conducir tanto a la subordinación del ordenamiento estatal al internacional (en el que también se fundamentaría el ordenamiento comunitario), como, a la inversa ${ }^{38}$. En el primer caso, la validez del ordenamiento estatal se derivaba de una norma de Derecho internacional general, «el principio de eficacia del poder del Estado en un determinado territorio» ${ }^{39}$, en el que se hallaría la cúspide del ordenamiento y, con ello, en cierta medida la soberanía; y en el segundo caso, la validez del ordenamiento internacional se derivará de la norma suprema del Estado, normalmente su Constitución, a la luz de la cual se incorporarían al ordenamiento el Derecho internacional y el derecho comunitario europeo. Este último, no obstante, podría poner dicha supremacía a disposición del ordenamiento internacional, mediante la traslación del ejercicio de la competencia sobre las competencias a las normas internacionales o comunitarias europeas.

Sin embargo, resultaría paradójico fundamentar la validez del ordenamiento estatal en una norma del sistema normativo internacional, el «principio de eficacia», cuando su contenido (la eficacia) se ha de constituir, en tanto realidad empirica y no sólo normatividad $i d e a l$, en la condición necesaria para conceder validez al sistema jurídico ${ }^{40}$. En efecto, el derecho internacional está ciertamente debilitado en su eficacia general autónoma hasta el punto de que puedan caber serias dudas acerca de si la misma alcanza un punto suficiente para poder concederle validez autónomamente ${ }^{41}$. Y aunque la eficacia mínima de un ordenamiento en su conjunto no representa el fundamento de validez de sus normas, sí aparece como condición de ésta. Lo cierto es que las normas internacionales, y las comunitarias no serían ajenas a esto debido a su origen internacional, sólo son eficaces en la medida en que, respaldadas por la coacción ejercida por el Estado, se convierten en normas estatales y es en el seno de este último ordenamiento en el que alcanzan su eficacia mínima necesaria. Aceptar que dicha eficacia mínima venga asegurada por el ordenamiento estatal implica confundir la eficacia de éste con la del derecho internacional y comunitario, lo que es aún más absurdo, cuando el «principio de eficacia» se convierte a su vez en norma fundante del ordenamiento estatal.

La perspectiva que concede primacía al ordenamiento internacional (y por extensión al comunitario) a la hora de fundamentar la unidad del ordenamiento jurídico en su con-

37 En un sentido similar, SCHILLING, T. Rang und Geltung von Normen in gestuften Rechtsordnungen, Berlin Verlag/Nomos Verlag, Berlín/Baden Baden, 1994, pág. 424.

38 Cfr. KELSEN, H., Die Einheit von Völkerrecht und staatlichem Recht, en Klecatsky/Marcic/Schambeck (Hrsg.), Die wiener rechtstheoretische Schule, Europa Verlag, Viena y otros, 1968, págs. 2214 ss.

39 Que es lo que permitiría su reconocimiento internacional; cfr. KELSEN, H., Das Problem der Souveränität und die Theorie des Völkerrechts, ob. cit., págs. 239, 240, 241.

40 La norma fundamental presupuesta del Derecho internacional explicaría el por qué de la validez del sistema jurídico internacional, mientras que su eficacia mínima (que dependería fundamentalmente de la eficacia de los ordenamientos jurídicos estatales) determinaría el cuándo de dicha validez, que se constituye en presupuesto para poder fundamentar lógicamente la del ordenamiento jurídico en su conjunto; cfr. KELSEN, H., Reine Rechtslebre, Franz Deuticke, Viena, 1976 (reimpresión de la segunda edición de 1960), pág. 219.

41 Precisamente, como ponen de relieve algunas de las crisis internacionales más recientes, resulta difícil encontrar criterios normativos claros acerca de cuándo se pasa de un sistema de uso de la fuerza física basado en la autotutela a un sistema basado en el monopolio de dicho uso por unos entes internacionales con capacidad para imponerla por sí mismos, así como también resulta difícil filosófico-políticamente admitir la igualdad de todos los Estados, sujetos del Derecho internacional, imprescindible para aceptar aquella autotutela. 
junto se convierte en este punto en tautológica, pues resulta cuando menos dudosa la propia existencia jurídico-positiva de dicho ordenamiento al margen de los ordenamientos estatales. Ello es lo que explica que la unidad del ordenamiento haya de fundarse aún desde la perspectiva de la supremacía del ordenamiento jurídico estatal ${ }^{42}$. En nuestra opinión, el ordenamiento estatal es el único que todavía hoy en día puede conceder eficazmente al ordenamiento jurídico internacional, incluido el derecho comunitario, la única validez que éste realmente posee, su validez interna ${ }^{43}$. El Derecho internacional representa, así, el Derecho externo del Estado ${ }^{44}$. Externo porque ha sido creado por sujetos y mediante procedimientos no expresamente establecidos por él, ni en su norma suprema ni en sus normas subordinadas; mas Derecho del Estado pues su única validez real (positiva) se deriva del ordenamiento estatal, desde el momento en que éste puede sujetar las normas internacionales al respeto de unos determinados contenidos que se convierten así en su condición material de validez ${ }^{45}$. Fuera de los Estados las normas internacionales sólo son hechos que se transforman en normas jurídicas mediante la técnica del reenvío u otra técnica jurídica de similares efectos ${ }^{46}$.

En la medida en que el Derecho originario de la Unión (los Tratados constitutivos y sus modificaciones ulteriores) tienen un origen jurídico internacional, como han recordado tanto el TJUE, el BVerfG y otros Tribunales Constitucionales de los Estados miembros ${ }^{47}$, la posición jurídica de éste en el conjunto del ordenamiento jurídico como un todo corre la misma suerte que el Derecho internacional, toda vez que la Unión Europea ni ha asumido competencias directas en materia de regulación del uso de la coacción física, ni posee un aparato coactivo propio del que servirse para hacer valer la efectividad de su ordenamiento, que reposa únicamente en la coacción económica y en la voluntad de los Estados miembros de cumplimiento y autotutela. Y ello con independencia de que efectivamente hacia dentro del subordenamiento jurídico comunitario sea posible atribuir una función materialmente constitucional al Derecho originario de la Unión, que le permite constituir un ordenamiento jurídico autónomo y generar sus propios mecanismos de legitimación, más allá de la legitimación que le aportan los Estados miembros en las distintas fases de creación del derecho comunitario. Esta concepción formalmente monista está presente en la jurisprudencia del BVerfG cuando afirma que los Estados miembros de al UE continúan siendo permanentemente los «señores de los

42 De uno sólo, aquel ordenamiento jurídico estatal que represente el punto de vista de conocimiento del ordenamiento jurídico que utilice el actor jurídico o el científico del Derecho. De este modo, los demás ordenamientos estatales serían para cada Estado subsistemas normativos, que pueden ser integrados en él en la medida en que los reconozca a través del derecho internacional público o privado; en este sentido, cfr. KELSEN, H., Das Problem der Souveränität und die Theorie des Völkerrechts, ob. cit., págs. 187-188 ss.

43 Sobre la distinción entre validez interna y validez externa del Derecho internacional, cfr. MIRKINEGUETZEVITCH, B., Droit Constitutionnel international, Librairie du Recueil Sirey, París,1933, pág. 151.

44 En la terminología acuñada por ZORN, P., Die deutsche Staatsverträge, Zeitschrift für die gesamte Staatswissenschft, Vol. 36, 1980, págs. 1 ss.

45 Cfr. MIRKINE-GUETZEVITCH, B., Droit Constitutionnel international, ob. cit., pág. 166.

46 Cfr. LA PERGOLA, A., Poder exterior y Estado de Derecho, Salamanca, Ediciones Universidad de Salamanca, 1987, pág. 15; SCHILLING, T., Rang und Geltung in gestuften Rechtsordnungen, ob. cit., págs. 300-301.

47 Véase BVerfGE 123, 267, 347-348; DTC 1/2004, de 1 de diciembre, FJ $4^{\circ}$. Con independencia que desde el punto de vistan de su organización y funcionamiento, efectivamente, supere el modelo de una simple organización internacional (DÍEZ-PICAZO GIMÉNEZ, L. M., La naturaleza de la Unión Europea, ob. cit., págs. 8 ss.) 
tratados», y sobre todo, que «la fuente del poder comunitario y de la Constitución europea en sentido funcional que los constituye son los pueblos de Europa constituidos democráticamente en sus respectivos Estados», y que no cabe disolver la soberanía ad extra del Estado alemán en un Estado federal europeo ni transferir la competencia sobre las competencias, sin un proceso constituyente en el que el pueblo alemán ejerza su poder constituyente y se desprenda de su soberanía ${ }^{48}$.

\section{LOS MODELOS DE RELACIÓN ENTRE LA CONSTITUCIÓN NACIONAL Y EL DERECHO DE LA UNIÓN EUROPEA}

Aunque el derecho comunitario europeo tenga que ocupar la posición que le atribuya la Constitución del Estado, ello no impediría, ciertamente, que el ordenamiento estatal disolviese su soberanía en beneficio del ordenamiento de la Unión Europea, o que compartiese su supremacía y la competencia sobre las competencias con dicho ordenamiento supranacional, pero ello debe acontecer en los términos que establezca su Constitución nacional. Ésta suele organizar su relación de supremacía con respecto al ordenamiento de la Unión Europea básicamente conforme a tres modelos: el de supremacía compartida con el derecho comunitario europeo, el de supremacía de la Constitución material intangible y el de supremacía plena de la Constitución formal.

En efecto, cuando el ordenamiento estatal ha determinado que las normas elaboradas total o parcialmente por sujetos y procedimientos no previstos por ella ni por sus normas subordinadas han de ser consideradas a su mismo nivel en la jerarquía normativa y les ha atribuido el ejercicio del poder de reforma constitucional y no existe ningún contenido constitucional sustraído a dicho poder, se está ante el modelo de supremacía compartida con el ordenamiento internacional. La disolución de la soberanía estatal se produce regularmente mediante la celebración de tratados internacionales y la integración en organizaciones supranacionales por un procedimiento constituyente-constituido, con mayorías parlamentarias semejantes a las de la reforma constitucional ${ }^{49}$. La diferencia estriba en que la traslación de esta supremacía por parte de la Constitución estatal no tiene lugar en favor de otra norma cuyo procedimiento de creación es previsto por ella misma, como ocurre cuando se aplican las cláusulas de reforma constitucional internas, sino en beneficio de normas de creación externa cuya eficacia general autónoma es, como se ha visto, más que dudosa. La norma suprema del ordenamiento como unidad pasará, entonces, a estar compuesta por un conjunto aleatorio de normas, las comunitarias, cuya «positividad» al margen de los ordenamientos estatales se halla en tela de juicio por la inexistencia de un mínimo de eficacia fuera éstos ${ }^{50}$.

48 BVerfGE 89, 155 ss. y BVerfGE 123, 267, 348-349.

49 Cfr. el Art. 92 en relación con el Art. 91.3 de la Constitución holandesa, que requiere una mayoría de 2/3 de ambas cámaras para ratificar tratados contrarios a la Constitución, idéntica a la requerida por el Art. 137.4 para reformar la constitución; o el Art. 50.3 que remite a las previsiones de reforma constitucional del Art. 44.1 y 2 de la Constitución austriaca, aunque se discute, respecto de este último, que esta posibilidad de cesión afecte también a la competencia de reforma total, cfr. ÖHLINGER, T., Verfassungsrechtliche Aspekte eines Beitritts Österreichs zu der Europäischen Gemeinschaft, Manz, Viena, 1988, pág. 48. 
Una segunda opción es aquella que, desdoblando la Constitución del Estado en dos, las normas constitucionales ordinarias, por un lado, y el núcleo constitucional intangible, integrante de una especie de «supra-constitución material», por otro, admite la preeminencia del derecho de la Unión respecto de las primeras, cuyo ámbito de aplicación estaría a disposición de las normas comunitarias, una vez ratificadas por los procedimientos constitucionalmente previstos — que habitualmente coinciden con los de la reforma constitucional- ${ }^{5}$, pero lo subordina al segundo, verdadera Constitución, cuya existencia sería en todo caso indisponible para los poderes constituidos internos o externos. Esta es la postura que adoptada por el ordenamiento constitucional alemán en virtud de los Arts. 23 y 79 III GG GL $^{52}$, pero también por el italiano sobre la base del Art. 11 en relación con el Art. $139 \mathrm{CI}^{53}$ y el francés con apoyo en los Arts. 54, 88-1, 88-2 y $89 \mathrm{CF}^{54}$, así como los ordenamientos constitucionales de nuevos Estados miembros de la Unión Europea como la República Checa ${ }^{55}$. Esta supra-constitución material estaría constituida por un núcleo de valores y principios fundamentales (entre los que se encuentran los principios estructurales del ordenamiento y los derechos fundamentales), identificativos del orden constitucional, que devendrían indisponibles para el poder de reforma constitucional tanto interno como externo. En realidad, en este modelo la disolución de la soberanía jurídica del ordenamiento del Estado ya se ha realizado a favor de aquéllos valores integrantes de esa Constitución material, que por su naturaleza su-

50 Sobre este entendimiento parcial de la positividad vinculado a la eficacia general del ordenamiento, cfr. ALÁEZ CORRAL, B., Los límites materiales a la reforma de la Constitución española de 1978, ob. cit., págs. 111 ss.

51 No se entra aquí en las razonadas críticas que se han vertido sobre los distintos problemas que plantean la interpretación de esas disposiciones constitucionales respecto de las modificaciones (tácitas) de las Constituciones nacionales mediante las denominadas «cláusulas evolutivas», «cláusulas-pasarela» y «cláusulas freno de emergencia»del Tratado de Lisboa; sobre ello CLASSEN. C., ¿Fortalecimiento recíproco del Bundestag o lecho constitucional del Procustes? Acerca de la Sentencia del Tribunal Constitucional federal sobre el Tratado de Lisboa, Teoría y realidad Constitucional, n 25, 2010, págs. 246 ss.

52 Conforme al Art. 23.I GG, in fine, la constitución de la Unión Europea, así como las modificaciones de los tratados constitutivos y de reglas equivalentes, a través de las cuales se modifique el contenido de la Grundgesetz o se complete el mismo, o se posibiliten modificaciones o adiciones a la misma estarán sometidas al Art. 79.II y III GG, es decir, a las formalidades y límites materiales de la reforma constitucional.

53 El Art. 11 CI permite a la república italiana conceder las limitaciones de soberanía necesarias para integrarse en la Unión Europea, y el Art. 139 CI proscribe toda reforma constitucional de la forma republicana de gobierno, lo que según la doctrina mayoritaria no solo se identifica con la forma de provisión de la Jefatura del Estado, sino también con la los principios esenciales de la forma de Estado democrático y social de derecho. Sobre dichos límites a la integración europea, cfr. CARTABIA, M., Principi inviolabili e integrazione europea, Giuffré, Milán, 1995, págs. 150 ss. y jurisprudencia de la Corte Constitucional a partir de la Sentencia $\mathrm{n}^{\circ} 232$ de 1989.

54 Los Arts. 88-1 y 88-2 CF regulan la pertenencia de Francia a la Unión Europea y la cesión de competencias a dicha organización supranacional, mientras que el Art. 54 prevé el control previo de constitucionalidad de los tratados internacionales (incluidos los de la UE) que quiera ratificar Francia y la necesidad de previa reforma constitucional en caso de contradicción entre dichos Tratados y la Constitución, fijando el Art. 89 in fine CF, al igual que hacía la Constitución italiana, que la forma de gobierno republicana es irreformable, lo que incluye los principios esenciales de la forma de Estado democrático de derecho. Sobre estos límites ya BEAUD, O., La souveraineté de l'Etat, le pouvoir constituant et le Traité de Maastricht, Revue française de Droit administratif, $\mathrm{n}^{\circ}$ 9, 1993, págs. 1045 ss, 1067-1068, y en la jurisprudencia francesa la Decisión CC 97-394 de 31.12.1997 sobre la ratificación del Tratado de Amsterdam de 2 de octubre de 1997.

55 Véase el Art. 9.2 y el Art. 10.a Const. Checa, tal y como han sido interpretados por la Sentencia del Tribunal Constitucional checo de 26 de noviembre de 2008. 
prapositiva, tienen un carácter estático y no son modificables, sino únicamente substituibles por otros nuevos al margen de las normas de la Constitución estatal, esto es, por un procedimiento constituyente originario, con los riesgos que ello conlleva para la diferenciación del sistema jurídico.

Finalmente, en tercer lugar, el modelo de soberania plena de la Constitución formal requiere la necesaria conformidad constitucional de los productos normativos procedentes parcial (derecho comunitario originario) o totalmente (derecho comunitario derivado) de sujetos cuya existencia no ha sido reglada de manera directa por el ordenamiento jurídico estatal, pero cuya relevancia jurídica sí ha sido establecida por éste. En tales casos, la disolución de la soberanía constitucional sólo puede tener lugar tras una previa reforma constitucional que altere la naturaleza suprema de la Constitución estatal o el ámbito espacial de su supremacía. Este último es, en nuestra opinión, el modelo dogmático por el que ha optado la CE de 1978 como expresión de la «autorreferencialidad» y «positividad» del ordenamiento del que es cúspide, cuya previsión en su Art. 93 de la incorporación en nuestro ordenamiento de subordenamientos externos, como el de la Unión Europea, se articula a un nivel infraconstitucional ${ }^{56}$, sin perjuicio de la eficacia interpretativa que tanto los Tratados de la Unión como el derecho derivado puedan desplegar ex Art. 10.2 CE y que no se opone a lo anterior ${ }^{57}$. Conforme a la cláusula de supremacía constitucional del Art 9.1 CE y a los Arts. 95 y 96 CE, relativos a las condiciones de la incorporación al ordenamiento español de los tratados internacionales - y por conexión del derecho comunitario derivado- la ratificación de tratados internacionales, incluidos los de la Unión Europea, en ningún caso supone el reconocimiento de la supremacía o paridad jerárquica de las normas constitucionales y las internacionales o comunitarias, entre otras razones porque no se produce a través de una reforma de la Constitución española, ni cabe entender que se ha cedido esa competencia a la organización supranacional, dado que solo se puede ceder el ejercicio de competencias "derivadas" de la Constitución, no de competencias constituyentes $^{58}$. La primacía del derecho comunitario está sujeta, por tanto, a la norma que le ha otorgado su condición de tal, la CE de 1978, es decir, a la regla de tipo constituti$v 0^{59} \sin$ cuya existencia su validez no sería posible. A esta categorización de nuestro siste-

56 El Art. 93 CE prevé que la cesión del ejercicio de competencias derivadas de la constitución se realice por Ley orgánica, y no mediante una reforma constitucional, cuyas mayorías de aprobación y rigidez son, a la luz de los Arts. 167 y 168 CE, claramente más elevadas que las de la mayoría absoluta del Congreso de los Diputados prevista en el Art. 81 CE.

57 El Tribunal Constitucional ha variado su doctrina sobre la relevancia constitucional de las cuestiones prejudiciales y ha planteado en su ATC 86/2011, de 9 de junio la primera cuestión prejudicial ante el TJUE precisamente para resolver la cuestión interpretativa del alcance de diversas normas de derecho comunitario originario y derivado que podían incidir interpretativamente en la determinación del alcance del derecho de defensa del Art. 24.2 CE.

58 Ya la DTC 1/1992, de 1 de julio, FF.JJ. $4^{\circ}$ y 5․ En este mismo sentido, ALÁEZ CORRAL, B. Soberanía constitucional e integración europea, ob. cit., págs. 539-548; y PUNSET BLANCO, Soberanía estatal e integración europea, ob. cit., págs. 148-150. Por el contrario, ha querido ver esta traslación de la competencia constituyente REQUEJO PAGÉS, J. L., Sistemas normativos, Constitución y ordenamiento. La Constitución como norma sobre la aplicación de normas, Madrid, Mc Graw Hill, 1995, págs. 256-257.

59 Sobre las reglas de tipo constitutivo, como reglas que establecen condiciones necesarias (y no siempre necesariamente suficientes) para la producción normativa, cfr. SEARLE, J.R., Speech Acts. An Essay in the Philosophy of Language, Cambridge, University Press, 1970 págs. 33-34. 
ma constitucional en el tercer modelo le aporta algo de oscuridad la DTC 1/2004, de 13 de diciembre, con su distinción entre la primacía del Derecho de la Unión incluso sobre el Derecho constitucional español y el mantenimiento de la supremacía de la CE de 1978 respecto (solo) de las estructuras constitucionales básicas y el sistema de valores y principios fundamentales $\left(\mathrm{FJ} 4^{0}\right)^{60}$, que aparece como una vía intermedia entre el pluralismo y el monismo con primacía del derecho estatal y como una aproximación también al modelo alemán de soberanía de una Supra-Constitución material. Sin querer entrar aquí en un análisis detallado, la distinción resulta insatisfactoria ${ }^{61}$. No solo porque en una constitución reformable totalmente, como la española, no hay una expresa indicación de esa SupraConstitución material ${ }^{62}$, sino sobre todo porque precisamente si la supremacía en la validez permanece en manos de la Constitución nacional, como afirma la DTC 1/2004, la primacía en la aplicación del Derecho comunitario europeo padecería dos características inaceptables: de un lado, implicaría una imposible suspensión de la Constitución en las materias de competencia de la Unión, lo que no parece muy congruente ni con la prohibición de celebrar tratados inconstitucionales, ni con las menos cualificadas mayorías que se requieren para su celebración en contraste con las mayorías de reforma constitucional; y de otro lado, no sería una primacía absoluta, como requiere la jurisprudencia del TJUE, en la medida en que los Tribunales constitucionales internos se reservan un poder de control del derecho comunitario para garantizar la supremacía en la validez, es decir, parte de la Kompetenz-Kompetenz.

\section{LAS DOS FACETAS DE LA COMPETENCIA SOBRE LAS COMPETENCIAS COMO CONTENIDO NORMATIVO DE LA SOBERANÍA}

\section{LA PRESERVACIÓN DE LA ESTATALIDAD Y LA IDENTIDAD CONSTITUCIONAL EN MANOS DE PODERES EMANADOS DE UN PUEBLO NACIONAL}

La soberanía del ordenamiento jurídico se identifica, pues, con la atribución normativa de la competencia sobre las competencias a las normas supremas de los Estados miembros de la Unión. Esta competencia sobre las competencias posee dos facetas que constituyen su contenido normativo y que han sido plasmadas por la jurisprudencia del BVerfG sobre la integración europea, aunque de forma desigual y no siempre suficien-

60 De acuerdo con esa distinción, sin embargo, PUNSET, R. Soberanía estatal e integración europea, ob. cit., págs. 159-160.

61 También MATÍA PORTILLA, J., Dos constituciones y un solo control: el lugar constitucional del Estado español en la Unión Europea (Comentario a la DTC 1/2004, de 13 de diciembre), REDC, n 74, 2005 págs. 349-353. Si admite la distinción, sin embargo, TORRES DEL MORAL, A., Relaciones entre la Unión Europea y los Estados miembros según el Tratado constitucional europeo. Principios que las rigen, Revista de Derecho Político, n 65, 2006, pág. 104.

62 Como atestigua la dicción del Art. 168 CE con su previsión de una reforma total y de la reforma de las estructuras y principios fundamentales del ordenamiento español, no existen en nuestro sistema jurídico cláusulas de intangibilidad absolutas ni se pueden deducir límites implícitos a la reforma constitucional; cfr. ALÁEZ CORRAL, B., Los límites materiales a la reforma de la Constitución española de 1978, ob. cit., págs. 310 ss., 328 ss. 
temente adecuada al texto de la Grundgesetz. La primera de ellas hace referencia a la capacidad del Estado miembro para revertir la cesión de competencias y, en su caso, para abandonar unilateralmente la Unión Europea ${ }^{63}$, para lo cual, además de tratarse de una limitada cesión de competencias singulares o, con palabras más conocidas, del mero «ejercicio de competencias derivadas de la Constitución», el Estado miembro debe conservar en manos de sus órganos constitucionales un poder normativo intransferible que le permita, en su caso, deshacer esa transferencia de competencias, es decir, un poder legislativo o de reforma constitucional de igual rango que el que permitió su cesión y, desde luego, en exclusiva el poder constituyente originario ${ }^{64}$.

Para garantizar esta faceta de la competencia sobre las competencias, y en la medida en que en el caso de Alemania las transferencias de poder público a la Unión Europea tienen valor de reforma constitucional, el BVerfG recuerda, con base en el Art. 23.I GG - tímidamente en la Sentencia Maastricht y de manera ya decidida en la Sentencia Lisboa-, el sometimiento de los sucesivos pasos del proceso de integración europea a las formalidades del procedimiento de reforma de la Grundgesetz y al respeto de la identi-

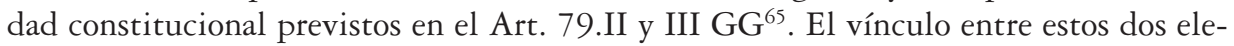
mentos (la preservación en manos de Alemania del poder de disposición sobre el proceso de integración y el respeto a los elementos de la identidad constitucional de la Grundgesetz) está constituido, para el BVerfG, por el pueblo alemán, en el que se residencia la soberanía (Art. 20.I GG), pues a través del mismo se expresa el principio democrático - uno de los contenidos intangibles de la identidad constitucional alemana, sino el más importante- y a él le corresponde la titularidad del poder constituyente originario (Art. 146 GG) —único habilitado para hipotéticamente ceder la competencia sobre las competencias e integrar a Alemania en un futuro Estado federal europeo-.

La norma constitucional que recoge el principio de soberanía popular exige la derivación del poder del Estado a partir del ente «pueblo», lo que se logra mínimamente con que en éste resida y permanezca la titularidad del poder constituyente originario. Una primera dificultad de esta interpretación del principio de soberanía popular reside en que este poder constituyente al que se refieren la jurisprudencia y la doctrina mayoritaria alemana es el poder constituyente originario, no el constituyente-constituido $^{66}$, por lo que posee una naturaleza más política que jurídica ${ }^{67}$. La razón de que así se haga estriba tanto la necesidad de colmar el defectuoso modo de

63 No importa que tenga que hacerlo a través de un procedimiento inicialmente negociado, en virtud del Art. 50 TUE, pues en último extremo si la negociación no llega a un término consensuado la retirada será efectiva automáticamente transcurridos dos años desde la notificación unilateral del Estado de su voluntad de retirada.

64 Cfr. BVerfGE 123, 267, 348-349 y DTC 1/2004, de 13 de diciembre, FJ $4^{\circ}$.

65 BVerfGE $123267,343-344$

66 Cfr. BVerfGE 123, 267, 344, 350; BÖCKENFÖRDE, E. W., §22 Demokratie als Verfassungsprinzip, en Isensee/Kirchhof (Hrsg.), Handbuch des Staatsrechts der Bundesrepublik Deutschland, C.F. Müller, München, 1987, pág. 890, Rdn. 6-7. Sobre el carácter realmente existente del poder constituyente originario, cfr. BÖCKENFÖRDE, E. W., Die verfassunggebende Gewalt des Volkes-Ein Grenzbegriff des Verfassungsrechts, en BÖCKENFÖRDE «Staat, Verfassung und Demokratie. Studien zur Verfassungstheorie und zum Verfassungsrecht», Suhrkamp, Frankfurt a.M., 1991, págs. 94 ss.

67 Ideológica diríamos; cfr. RÖLLECKE, G., Verfassungsgebbende Gewalt als Ideologie, en Deppenheuer (Hrsg.), «Aufgeklärter Positivismus. Ausgewäblte Schriften zu den Voraussetzungen des Verfassungsstaates», 
nacimiento de la Grundgesetz desde el punto de vista de la legitimación democrática de origen, como en el tradicional reconocimiento histórico-político de este principio $^{68}$, que lo había convertido en necesario fundamento de toda Constitución democrática ${ }^{69}$. Ahora bien, el pueblo siempre ha de actuar jurídicamente conformado, es decir, como poder constituido a través de órganos representativos o colectivos, sea en ejercicio de funciones constituidas sea en ejercicio de funciones constituyentes ${ }^{70}$.

Una segunda dificultad de este entendimiento del principio de soberanía popular que realiza el BVerfG respecto del control de constitucionalidad del proceso de integración europea es su confusión e identificación con el principio democrático. Ambos, sin embargo, no deben ser confundidos, sobre todo desde el momento en que la titularidad del poder constituyente del pueblo no garantizaría una «legitimidad democrática de ejercicio», sino sólo «de origen». Para lograr, por tanto, que la democracia sea una forma de Estado, que haga real la participación de los sometidos al poder ${ }^{71}$ en el ejercicio del poder, sobre todo a través de los derechos de participación en el poder público que curiosamente el BVerfG vincula al respeto de la dignidad humana ${ }^{72}$, es preciso que dicho ejercicio del poder se organice conforme a unos determinados mecanismos (de participación del ciudadano en la formación de la voluntad estatal ${ }^{73}$ ), principios (de legitimación democrática funcional-institucional, organizativo-personal y material) y estructuras que garanticen que el «pueblo» es efectivamente titular de todo el poder estatal ${ }^{74}$.

En este sentido tiene razón el BVerfG al considerar que tanto el dogma de la soberanía popular como el principio democrático pueden verse afectados cuando el ordena-

C.F. Müller, Heidelberg, 1995, págs. 158 ss. Igualmente crítico con la posibilidad de referir en términos jurídicos la existencia del poder constituyente del pueblo, ISENSEE, J., Das Volk als Grund der Verfassung, Westdeutscher Verlag, Opladen, 1995, págs. 33-34 ss.

68 BÖCKENFÖRDE, E. W., §22 Demokratie als Verfassungsprinzip, ob. cit., pág. 890, Rdn. 4.

69 HERZOG, R., Art. 20 GG, en Maunz/Dürig (Hrsg.), Grundgesetz Kommentar, C.H. Beck, München, pág. 5, Rdn. 8; en idéntico sentido, BÖCKENFÖRDE, E. W., \$22 Demokratie als Verfassungsprinzip, ob. cit., pág. 891, Rdn. 7.

70 Cfr. ALÁEZ CORRAL, B. Los limites materiales a la reforma de la Constitución española de 1978, ob. cit., págs. 148-150.

71 Este nuevo entendimiento del "pueblo» no siempre (no en todos los procesos normativos) coincide ya con la colectividad de nacionales del Estado, a cuyos miembros en cuanto tales el ordenamiento atribuye distintos derechos de participación para la legitimación del ordenamiento, como sostiene BÖCKENFÖRDE, E. W., §22 Demokratie als Verfassungsprinzip, ob. cit., págs. 903-904, Rdn. 26 ss.

72 BVerfGE 123, 267, 341

73 Cfr. SCHNEIDER, H. P., Eigenart und Funktionen der Grundrechte im demokratischen Verfassungstaat, en Perels (Hrsg.), Grundrechte als Fundament der Demokratie, Suhrkamp, Frankfurt am Main 1979, págs. 28 ss. La concreción más directa de aquéllos es el derecho fundamental a participar por medio del cuerpo electoral, seleccionado exclusivamente a partir de los criterios de nacionalidad y de edad, en la elección de un órgano constitucional, la Cámara baja, en la que se concentran las principales funciones de creación normativa; véase al respecto el Art. 38 I GG conforme a la interpretación que le ha dado el BVerfGE 47, 253, 269, o en la BVerfGE 89, 155, 171-172. En contra de esta «materialización» y «subjetivización», del contenido en principio exclusivamente formal del Art. 38 I GG se muestra GASSNER, U. M., Kreation und Repräsentation. Zum demokratischen Gewährleistungsgehalt von Art. 38 Abs. I S. 1 GG, Der Staat, Vol. 34, N 3, 1995, págs. 433 ss.

74 Cfr. BÖCKENFÖRDE, E.W., §22 Demokratie als Verfassungsprinzip, ob. cit., pág. 893, Rdn. 9.; también Herzog, R., Art. 20 GG, ob. cit., págs. 32 ss., Rdn. 14 ss. 
miento jurídico abre sus puertas a la creación normativa por órganos y procedimientos que él mismo no ha creado $^{75}$, y que dicha afectación no puede traspasar el límite de vaciarlos de contenido o hacerlos irreconocibles conforme a su caracterización constitucional, pues ello sería equivalente a vulnerar las estructuras y principios fundamentales que conforman la identidad constitucional intangible. El primero de los dogmas se vería alterado en su esencia, si se produjese una transferencia del poder constituyente (originario), lo que estaría constitucionalmente proscrito ex Art. 79.III GG en relación con el Art. 146 GG. Respecto del segundo, cabe señalar, que el derecho a participar en la cadena de legitimación antes descrita se instrumenta fundamentalmente a través del derecho de participación en los asuntos públicos directamente o a través de representantes ${ }^{76}$, los cuales deben estar dotados de competencias propias, tanto materiales como de control, suficientes como para que la cadena no se rompa ${ }^{77}$. Cuándo dicha afectación va más allá de lo constitucionalmente permitido hasta afectar a la esencia de la identidad constitucional democrática del Estado es una cuestión polémica ${ }^{78}$, dado el carácter «principial»y abierto del principio estructural de Estado democrático, pero ello no excluye su utilización como límite al proceso de integración europea, ni tampoco la excluye el que la génesis histórica de la cláusula de intangibilidad del Art. 79.III GG no estuviese pensada para la Unión Europea sino para evitar que se repitieran sucesos como la destrucción de la República de Weimar por el nacionalsocialismo desde dentro ${ }^{79}$.

Ahora bien, en la determinación de cuándo se produce la conculcación del principio democrático, como principio intangible de la Supra-Constitución material, no se pueden

75 BVerfGE 123, 267, 344-345. También HERZOG, R., Art. 20 GG, ob. cit., págs. 72 ss., Rdn. 103; sobre la influencia del TUE en los principios de legitimación democrática antes mencionados, véase ya CLASSEN, C. D., Europäische Integration und demokratische Legitimation, Archiv des öffentlichen Rechts, Vol. 119, $\mathrm{N}^{\circ} 2$, 1994, págs. 244 ss.

76 Véase el Art. 23. 1 CE y el Art. 20 I GG.

77 Cfr. en este sentido BVerfGE 89, 155, 182 ss. y BVerfGE 123, 267, 342 ss.

78 Parte de la doctrina alemana consideró ya hace tiempo (cfr. MURSWIEK, D., Maastricht und der pouvoir constituant, Der Staat, no 32, 1992, págs. 161 ss.) que el poder constituyente del pueblo —Art. 146 GG- le habría sido hurtado al mismo por el legislador de reforma constitucional mediante una atribución legislativa de competencias constitucionales a la Unión Europea, cuya extensión, tanto cualitativa como cuantitativamente hablando, sería contraria al principio democrático; mientras, otra buena parte de la doctrina (cfr. entre otros ZULEEG, M., Demokratie in der Europäischen Gemeinschaft, Juristenzeitung, 1993, págs. 1069 ss), así como en definitiva el BVerfG en su fallo de las Sentencias Maastricht y Lisboa (BVerfGE 89, 155 y BVerfGE 123, 267) han considerado que el mínimo garantizado del principio democrático se halla por el momento suficientemente protegido, no obstante la apertura ad extra del ordenamiento, siempre que, de un lado, se avance en la democratización de las instituciones europeas por la vía del Parlamento europeo, pero también, de otro lado, siempre que, bajo un escrupuloso respeto al principio de habilitación competencial singular, el Parlamento nacional conserve suficientes competencias, tanto materiales como de control de la política europea del Gobierno.

79 Pues su interpretación debe adecuarse a la dogmática constitucionalmente adecuada del conjunto de la Grundgesetz y no se puede realizar solo con base en los tradicionales criterios hermenéuticos como el histórico o el teleológico (véase UNRUH, P., Der Verfassungsbegriff des Grundgesetzes, Mohr Siebeck, Tübingen, 2002, págs. 443-444). En un sentido diverso, sin embargo, rechazando con base en una interpretación histórico-teleológica la aplicabilidad de la «cláusula de eternidad» a la pérdida de soberanía como consecuencia de la integración europea, SCHÖNBERGER, C. Lisbon-Maastricht's Epigones at sea, German Law Journal, Vol. 10, nº 8, 2009, pág. 1208; HALBERSTAM/MÖLLERS, The German Constitutional Court says «Ja zu Deutschland», German Law Journal, Vol. 10, nº 8, 2009, pág. 1254. 
confundir en uno el principio democrático y el dogma de la soberanía popular, como hace el BVerfG influido por una precomprensión étnico-cultural y prejurídica del pueblo alemán $^{80}$, que tiene un muy débil apoyo en el texto constitucional y que muestra un implícito sesgo nacionalista difícilmente conciliable con el europeísmo e internacionalismo que expresamente plasma la Grundgesetz ${ }^{8}$. En efecto, que todo el poder haya de emanar del pueblo es un corolario de que la Constitución organice el Estado conforme al principio democrático, pero no identifica a ambos ni agota el principio democrático en dicha cadena de legitimación sacando fuera del sistema jurídico positivo al pueblo soberano $^{82}$. El poder público puede emanar del pueblo de muchas formas, como pone de relieve el Art. 20.I GG (elecciones y decisiones) y a través de múltiples órganos legislativos, ejecutivos y judiciales, no solo a través de la elección representativa del Bundestag alemán $^{83}$. Aún aceptando que el pueblo del que emana todo el poder sea (implícitamente) el pueblo alemán — pues expresamente la Grundgesetz atribuye la soberanía solo al pueblo_ ${ }^{84}$, se puede satisfacer la cadena de legitimación con la participación de éste en diversos grados de intensidad, a través de una pluralidad de órganos y de múltiples formas y procedimientos, unos de representación general, proporcional y nacional (Bundestag), otros de representación territorial no proporcional y federal (Bundesrat), y otros, finalmente, supranacionales, de representación general de los ciudadanos europeos pero también de representación territorial de los Estados miembros, entre los que se incluyen el Parlamento Europeo, el Consejo europeo y las demás instituciones de la Unión. No es preciso que en todos los procesos normativos participen solo los nacionales, puesto que la jerárquica limitación de las potestades normativas ejercidas por los distintos órganos del Estado garantizan que al final el pueblo nacional sea la última fuente de ligitimidad siempre que sea el único que puede participar en el ejercicio del poder constituyente-constituido ${ }^{85}$. Y tampoco tiene por qué verse en el denominado déficit democrático de la Unión una conculcación del principio democrático, sino únicamente una divergencia con respecto al parlamentarismo nacional (déficit parlamentario), que, sin embargo, ha sido autorizada por la cláusula de apertura europea de la Grundgesetz y que por esa misma razón no puede ser esencial al contenido intangible del principio democrático.

80 Cfr. BVerfGE 123, 267, 358 ss.

81 En este mismo sentido crítico con este entendimiento del principio democrático que muestra el BVerfG sobre todo en la sentencia Lisboa, aunque ya indicado en la sentencia Maastricht, cfr. HÄBERLE, P., La regresiva «Sentencia Lisboa» como «Mastricht-II» anquilosada, ob. cit., págs. 422-425; SCHÖNBERGER, C., Lisbon-Maastricht's Epigones at sea, ob. cit., págs. 1211-1216; HALBERSTAM/MÖLLERS, The German Constitutional Court says «Ja zu Deutschland», ob. cit., págs. 1247-1249.

82 Cfr. BASTIDA FREIJEDO, F., La soberanía borrosa: la democracia, Fundamentos, Vol. I, 1998, págs. 389 ss.

83 Como pone de relieve la crítica a la lectura nacionalista y mayoritaria e igualitarista del principio democrático que hace el BVerfG en su Sentencia Lisboa, errada tanto respecto del derecho constitucional alemán como respecto del derecho de la Unión Europea; cfr. SCHÖNBERGER, C., Lisbon-Maastricht's Epigones at sea, ob. cit., págs. 1211 ss.; HALBERSTAM/MÖLLERS, The German Constitutional Court says «Ja zu Deutschland», ob. cit., págs. 1247-1249.

$84 \mathrm{Al}$ contrario de lo que sucede en el ordenamiento español, en el que el Art. 1.2 CE expresamente atribuye la soberanía nacional del pueblo español.

85 ALÁEZ CORRAL, B., Nacionalidad, ciudadanía y democracia: ¿ A quién pertenece la Constitución?, CEPC, Madrid, 2006, págs. 228 ss. 
De ahí que para mantener la legitimación democrática del poder conforme a la Grundgesetz, incluido el dogma de la soberanía popular, no sea preciso, como hace el BVerfG en la Sentencia Lisboa abundando en la confusión del plano prejurídico y del plano jurídico, que cinco ámbitos concretos competenciales de poder permanezcan en todo caso en manos de los órganos constitucionales alemanes sujetos a la cadena de legitimación exclusiva del pueblo «alemán», a saber: el derecho penal formal y material, el papel e intervención de las fuerzas de seguridad del Estado y de las fuerzas armadas, el núcleo del derecho fiscal y presupuestario, los aspectos esenciales del Estado social, y el régimen jurídico nuclear de la nacionalidad, educación, familia, lengua y religión ${ }^{86}$. Bastaría con que permaneciese en manos de los ciudadanos alemanes, a través de sus representantes nacionales, el poder constituyente para darse y modificar su identidad constitucional, para seguir teniendo la llave de su destino en solitario o entregar dicha llave a un poder constituyente paneuropeo, dado que este poder es intransferible a los poderes constituidos europeos en los que también participa el pueblo alemán en condiciones de igualdad con los demás pueblos europeos. Es decir, bastaría con que no se transfiera a la Unión Europea la competencia sobre las competencias ${ }^{87}$. Y también se requeriría que el pueblo alemán pueda seguir participando a través de sus representantes federales, estatales, y europeos, en los procesos de creación normativa supranacionales en los que por voluntad de sus representantes nacionales se ha integrado como consecuencia de las sucesivas cesiones de competencias. Cualquier otra exigencia estaría orientada a reconstruir de forma político-culturalmente homogénea la existencia democrática y las características del pueblo alemán, en contra del pluralismo y la libertad constitucionalmente garantizados a sus integrantes, así como al margen de la apertura europea de la Grundgesetz.

\section{El CONTROL DE CONSTITUCIONALIDAD POR los TRIBUNALES CONSTITUCIONALES NACIONALES DEL RESPETO DE LA ESTATALIDAD Y LA IDENTIDAD CONSTITUCIONAL}

La segunda faceta de la competencia sobre las competencias hace referencia a la posibilidad de que los órganos encargados de la justicia constitucional en los Estados miembros de la Unión hagan valer respecto del proceso de integración europea la primera faceta de la competencia sobre las competencias antes mencionada, es decir, la supremacía de toda o de parte de la Constitución del Estado miembro. Así, el BVerfG ha afirmado su competencia de control de constitucionalidad sobre el derecho de la Unión (incluido el derivado), primero solo y de forma contenida en relación con el respeto a los derechos fundamentales ${ }^{88}$, y después, desde las sentencias Maastricht y Lisboa, también en relación con el respeto del principio de atribución competencial singular y limitada, y de los principios integrantes de la Supra-Constitución material intangible ${ }^{89}$, aunque sea en una relación de cooperación con el Tribunal de Justicia de la Unión Europea y solo en casos gra-

86 BVerfGE 123, 267, 359 ss.

87 Cfr. CREMER, W., Lissabon-Vertrag und Grundgesetz, Jura, n 4, 2010, pág. 300.

88 Sentencias Solange I, BVerfGE 37, 271, 28o ss.; y Solange II, BVerfGE 73, 3339, 387.

89 BVerfGE 89, 155, 175; BVerfGE 123, 267, 350. 
ves en los que el atentado es palmario y suficientemente cualificado como para vulnerar los principios constitucionales afectados ${ }^{90}$.

La necesidad de ubicar en un órgano jurisdiccional esta faceta del contenido normativo de la competencia sobre las competencias aparece cuando se trata de resolver un conflicto entre ordenamientos que pretenden supremacía normativa por cualquiera de los sujetos que tiene atribuida la garantía de esa supremacía respecto de cada uno de los ordenamientos ${ }^{91}$. No importa que con la cesión de competencias constitucionales a la Unión Europea los ordenamientos europeos se han convertido en ordenamientos fragmentarios, ni tampoco que dicho proceso de fragmentación quede abierto en virtud de una cláusula constitucional de la que los Tribunales Constitucionales se convierten en aplicadores $^{92}$. Lo trascendente es dónde está residenciado el fragmento de poder público en torno al cual se articula el concepto normativo de soberanía, y qué papel sigue desempeñando la jurisdicción constitucional nacional en relación con él. Por ello, de las muchas implicaciones que tiene la cuestión del ejercicio de este control de constitucionalidad del proceso de integración europea por parte de los Tribunales Constitucionales de los Estados miembros, nos vamos a ocupar de dos: de un lado, de la relativa al fundamento y alcance de dicha competencia; y de otro lado, de la relativa a la naturaleza del parámetro de enjuiciamiento en aquellos casos, como el alemán, en los que éste está constituido por una Supra-Constitución material intangible.

En lo que respecta, en primer lugar, a la competencia del BVerfG para el control de constitucionalidad, ésta es consecuencia directa de la afirmación de la supremacía de la Supra-Constitución material alemana, cuya garantía está encomendada al BVerfG como órgano de control de constitucionalidad. También es la consecuencia de que se afirme el mantenimiento en manos del Estado alemán de la competencia sobre las competencias y de que consiguientemente se niegue que la última palabra, jurídicamente hablando, se haya transferido a la Unión Europea y corresponda a su Tribunal de Justicia, tal y como parece haberse impuesto en la jurisdicción y praxis comunitarias ${ }^{93}$. De acuerdo con esta última postura, rechazada por el BVerfG, el Tribunal Constitucional del Estado miembro aparecería como un mero fedatario de dicha transformación y se encontraría con que el reconocimiento de la supremacía del derecho de la Unión Europea implicaría la pérdida de supremacía de su propio fundamento de validez, la Constitución nacional, que tiene la específica función de garantizar. En una situación de desapoderamiento de esa faceta de la competencia sobre las competencias el Tribunal Constitucional nacional perdería buena

90 Sobre todo, la más reciente Sentencia Mangold de 2010, BVerfGE 126, 286, 304, respecto del control del principio de atribución competencial singular y limitada (ultra-vires).

91 Sobre las distintas formas de solventar los conflictos entre ordenamientos, tomando como ejemplo el del ordenamiento alemán en la sentencia de Maastricht, cfr. ARNOLD, R., Conflictos entre ordenamientos y su solución. El ejemplo alemán, ReDCE, nº 1, 2004, pág. 97 ss.

92 Sobre ello, cfr. BODGANDY, A., La integración europea a la luz de la Constitución alemana: una reflexión en torno a la Sentencia del Tribunal Constitucional Federal sobre el caso Maastricht, Cuadernos de Derecho Público, no 13, 2001, pág. 212-213.

93 En una suerte de competencia sobre las competencias de carácter judicial; cfr. WEILER, J.H.H., The Constitution of Europe. "Do the new clothes have an Emperor?", and other Essays on European Integration, Cambridge University Press, Cambridge, 1999, págs. 298 ss.; DÍEZ-PICAZO GIMÉNEZ, L. M., La naturaleza de la Unión Europea, ob. cit., págs. 28-29. 
parte de su específica función y legitimidad como órgano jurisdiccional, sobre todo si a dicha situación no se ha llegado por la vía del ejercicio del poder constituyente que cediese de forma constitucionalmente correcta dicha competencia sobre las competencias ${ }^{94}$. Además, en el caso de la pérdida de su competencia se mermaría la autoridad social del Tribunal Constitucional en el proceso de legitimación del sistema jurídico por dos motivos: primero, porque precisamente su decisión jurisdiccional opera como sustrato fáctico de la eficacia general del sistema jurídico, condición indispensable para presuponer válido el ordenamiento constitucional que le atribuye sus competencias de control de constitucionalidad ${ }^{95} \mathrm{y}$, por tanto, hace necesaria su autoridad legitimadora del mismo ante la sociedad $^{96}$; y segundo, porque la autoridad social del Tribunal Constitucional presupone la atribución por el propio texto constitucional de carácter jurisdiccional a sus decisiones, que han de ser la expresión de una argumentación jurídica y no de una mera argumentación política, es decir, presupone la recursividad de sus decisiones a un texto normativo que se presupone lógica y jurídico-positivamente por encima del propio Tribunal, lo que no ocurriría si el Tribunal coloca al texto constitucional como objeto de enjuiciamiento y no como argumento o parámetro de sus razonamientos, quedando éstos con ello huérfanos de racionalidad jurídica e integrados en el ámbito de los argumentos políticos ${ }^{97}$.

Pues bien, desde este último punto de vista, la posición del BVerfG respecto de su competencia de control de constitucionalidad del proceso de integración europea resulta ambivalente. De un lado, al afirmar dicha competencia, refuerza la normatividad de la Constitución nacional, su supremacía y, con ello, su propia legitimidad como órgano de la jurisdicción constitucional. Pero, de otro lado, la definición que realiza del parámetro de control no siempre se mantiene dentro de la órbita de la argumentación de un órgano jurisdiccional, pues, su reconstrucción interpretativa de las disposiciones de la Grundgesetz que recogen los principios intangibles no siempre tiene en cuenta la apertura y abstracción de éstas.

Ciertamente, la afirmación por parte del Tribunal Constitucional nacional de su competencia de control de constitucionalidad del proceso de integración europea no impide que, a través de la cesión de competencias jurisdiccionales a las instituciones europeas (a su Tribunal de Justicia), se pueda producir una cierta reducción de la extensión de dicha competencia, por ejemplo, en el ámbito de la tutela de los derechos fundamenta-

94 En este mismo sentido, LERCHE, P., Verfassungsgerichtsbarkeit in besonderen Situationen, C.H. Beck, München, 2002, págs. 24-26.

95 Cfr KELSEN, H., Wesen und Entwicklung der Staatsgerichtsbarkeit, en KELSEN, H., Wer soll der Hüter der Verfassung sein?, Mohr Siebeck, Tübingen, 2008 (texto de la edición de 1929), págs. 30 ss.

96 La legitimación del sistema jurídico procede de la disposición generalizada de los individuos a los que se dirigen las normas jurídicas a aceptar dentro de ciertos márgenes de tolerancia las decisiones que contienen dichas normas aun indeterminadas desde el punto de vista de su contenido, y a ello contribuye procedimentalmente la argumentación de órganos como los de la jurisdicción constitucional. Sobre este concepto de legitimación cfr. LUHMANN, N., Legitimation durch Verfabren, Neuwied, Berlín, 1969, pág. 28.

97 Sobre la diferenciación entre argumentación jurídica y argumentación política, véase, OTTO Y PARDO, I., Estudios sobre el poder judicial, Ministerio de Justicia, Madrid, 1989, págs. 76 ss.

98 Conforme a la Sentencia Solange II (BVerfGE 73, 339), el Tribunal Constitucional Federal alemán renunciaba a ejercer su control de constitucionalidad sobre los actos de derecho comunitario derivado en el ámbito de la tutela de los derechos fundamentales, «en tanto en cuanto» las Comunidades Europeas mantuviesen — a través del Tribunal de Justicia — un nivel de garantía de aquellos derechos sustancialmente equivalente. 
les ${ }^{98}$ — pero también en los términos de la determinación de una actuación competencial ultra vires de la Unión ${ }^{99}$ - , o que se puedan intentar compatibilizar los efectos de estas decisiones jurisdiccionales garantes de la supremacía constitucional con el cumplimiento de las obligaciones internacionales y europeas por parte de los Estados ${ }^{100}$. Pero, para que se mantenga esta segunda faceta de la competencia sobre las competencias basta con que los órganos de la jurisdicción constitucional de los Estados miembros dispongan de procedimientos para garantizar que el proceso de integración se desarrolla dentro de los límites del respeto al principio de atribución competencial limitada y a la cláusula de intangibilidad del Art. 79.III GG —entre ellos el principio democrático- que el Art. 23 GG le ha impuesto al legislador de la integración europea, y que su determinación en último extremo corresponda al Tribunal Constitucional Federal en tanto garante de que la competencia sobre las competencias permanece en manos de la Grundgesetz ${ }^{101}$.

El mantenimiento de la competencia del BVerfG — como la del resto de Tribunales Constitucionales de los Estados miembros- para controlar el respeto de los límites jurídico-constitucionales impuestos al proceso de integración europea es, a mi entender, la única forma válida de resolver la tensión generada entre Política y Derecho, al menos mientras no se produzca un proceso constituyente europeo jurídicamente reglado a partir de las Constituciones de los Estados miembros que conduzca a transferir explícitamente la competencia sobre las competencias a la Unión Europea. Es decir, mientras no se transfieran a la Unión las dos facetas en las que se plasma la Kompetenz-Kompetenz: tanto el poder constituyente-constituido que pasaría a ser un poder europeo (aunque pudiera ejercerse de forma federal), como, sobre todo, el poder de control de constitucionalidad. Ello no quita para que también se constate cómo el BVerfG, al tiempo que trata de marcar los límites de lo jurídicamente posible a las políticas de construcción europea, reintroduce de forma inconsciente una argumentación política en el proceso de interpretación constitucional de dichos abstractos límites, mermando con ello el imperio del Derecho que pretende afirmar.

La distinción entre la primacía aplicativa del derecho comunitario europeo y la reserva de la supremacía normativa de ésta de la que él es garante, que realiza el Tribunal Constitucional español ${ }^{102}$, tampoco cambia nada en este sentido. Si precisamente el Tribunal Constitucional español conserva su última potestad de control para garantizar la supremacía, es porque la primacía debe ceder allí donde el aplicador cualificado del de-

99 Según STEIN, T., La sentencia del Tribunal Constitucional alemán sobre el Tratado de Maastricht, Revista de Instituciones Europeas, n 3, 1994, págs. 764-765, el TJUE es el único órgano que debería ser competente para determinar esa extralimitación.

100 Un buen ejemplo de ello es la Decisión del Conseil Constitutionnel francés DC 2010/605, de 12 de mayo de 2010 .

101 Al amparo, en el caso alemán, del Art. 93.I GG; en el caso del Tribunal Constitucional español, de los Arts. 95 y 161.1 CE y del Art. 27 LOTC; y en el caso del Conseil Constitutionnel Francés, de los Arts. 61 y 62 CF y de los Arts. 23.2 y 23.5 de la Ordenanza nº 58/106, introducidos por la ley orgánica no 2009/1253, de 3 de diciembre, relativos a la nueva cuestión prioritaria de inconstitucionalidad ante el Consejo constitucional y los efectos vinculantes de sus decisiones, por poner algunos ejemplos.

102 DTC $1 / 2004$ de 13 de diciembre, F.J. 2-4º Un análisis de la misma y de las categorías primacía y supremacía utilizadas por el Tribunal Constitucional se puede ver en RODRÍGUEZ, A., ¿Quién debe ser el defensor de la Constitución española? Comentario a la DTC 1/2004, de 13 de diciembre, ReDCE, n 3, 2005, págs. 331-334. 
recho comunitario - el órgano de la jurisdicción constitucional-, puede utilizar como parámetro de validez de esa regla de aplicación preferente del derecho comunitario las preeminentes normas constitucionales que justifican su competencia de control. Una primacía aplicativa condicionada no es tal primacía. Y, si se lleva dicha primacía hasta sus últimas consecuencias incondicionadas, ello la convierte en una forma de primacía inconstitucional por ser una supremacía encubierta ${ }^{103}$.

Además, no se deben confundir las distintas condiciones de validez que la norma superior (suprema) puede imponer a las normas inferiores y que pueden afectar tanto a su proceso de creación (orgánico-procedimentales) como a su contenido (materiales). Desde esta perspectiva no es preciso que la jurisdicción constitucional las utilice todas y en todo momento como parámetro del control de constitucionalidad del Derecho comunitario europeo, pues tampoco lo hace con respecto a las normas de producción interna ${ }^{104}$. Basta con que posea el poder último de control respecto de algunas de ellas, las materiales, en los supuestos en que la contradicción no es superable mediante la concordancia práctica y la integración interpretativa, para que esta faceta de la Kompetenz-Kompetenz, y por tanto de la soberanía en sentido jurídico, permanezca en el Estado miembro. Y eso parece ser el caso tanto en la jurisprudencia de nuestro Tribunal Constitucional como en el la jurisprudencia del BVerfG, que habilitarían un control interno de la validez constitucional y no solo de la mera aplicabilidad del Derecho de la Unión ${ }^{105}$.

Por lo que se refiere, en segundo lugar, a la cuestión de la naturaleza de ese contenido material intangible que sirve de parámetro del control, la existencia en el Art. 79.III GG de una cláusula de intangibilidad expresa, conforme a la cual la identidad constitucional limita la acción constituyente-constituida tanto de los órganos constitucionales alemanes como del poder público europeo, convierte, utilizando la expresión de Bachof, en normas constitucionales inconstitucionales ${ }^{106}$ a aquellas normas internas o europeas que se opongan a los principios constitucionales esenciales recogidos en los Arts. 1 y 20 GG. Ahora bien, la jurisprudencia del BVerfG se muestra oscilante por lo que respecta a la naturaleza de dichos principios. Así, el expreso reconocimiento de naturaleza suprapositiva del contenido de la cláusula de intangibilidad y de la competencia del Bundesverfassungsgericht para medir las reformas del texto constitucional positivo a la luz del mismo, que aparece en la temprana decisión de posguerra, BVerfGE 1, 14 (Sentencia «Estado del suroeste»), da paso en la BVerfGE 30, 1 (Sentencia «escuchas telefónicas») y

103 Un intento de conciliación de ambas categorías, puede verse, sin embargo, en RODRÍGUEZ IZQUIERDO SERRANO, M. Primacía y subsidiariedad en la Unión Europea, ob. cit., págs. 77 ss.

104 Véase, por ejemplo, respecto del Tribunal Constitucional español, cómo, conforme a la doctrina de los «interna corporis acta» (STC 99/1987, de 11 de junio, FJ 1 a), la inobservancia de los preceptos (de los Reglamentos parlamentarios) que regulan el procedimiento legislativo podría viciar de inconstitucionalidad la ley cuando esa inobservancia altere de modo sustancial el proceso de formación de voluntad en el seno de las Cámaras; y otro tanto cabe decir de los vicios del proceso electoral (STC 105/2012, de 11 de mayo, FFJJ $7^{\circ}$ ss.), aunque se trate de normas interpuestas que concretan jurídicamente aspectos abiertos de las disposiciones constitucionales sobre el procedimiento legislativo o sobre el proceso electoral.

105 Con independencia de que los efectos de la declaración de inconstitucionalidad sean distintos a los que resultarían respecto de un acto de poder público interno y no puedan ser la nulidad ex tunc ni siquiera ex nunc y tenga que seguirse un proceso de denuncia del Tratado internacional en que consisten o del que traen causa; sobre ello, PUNSET BLANCO, R., Soberanía estatal e integración europea, ob. cit., págs. 152-153.

106 BACHOF, O., Verfassungswidrige Verfassungsnormen?, Mohr, Tübingen, 1951. 
más aún en la BVerfGE 109, 279 (Sentencia «espionaje acústico masivo») a un silencio sobre dicha naturaleza suprapositiva, que pudiera ser reflejo de un cambio de posicionamiento del Tribunal respecto de la naturaleza de dichos contenidos intangibles y respecto de la posición de la jurisdicción constitucional en relación con su normatividad. Sin embargo, este cambio se ve de nuevo relativizado con las afirmaciones que se vierten en la BVerfGE 123, 267, sobre el Tratado de Lisboa sobre el carácter prejurídico del pueblo alemán al que el Art. 20 GG imputa la soberanía o sobre la homogeneidad político-cultural que ese mismo pueblo debe mantener en cinco ámbitos esenciales para que no se vea menoscabado un principio democrático que se identifica erróneamente con la soberanía prejurídica del pueblo alemán ${ }^{107}$.

Esta es una cuestión relevante porque la posición de la jurisdicción constitucional varía según cuál sea la naturaleza del parámetro de enjuiciamiento de la constitucionalidad de las reformas constitucionales. Un Tribunal Constitucional que pretenda ser un órgano jurisdiccional ha de tener un parámetro de control que sea identificable con criterios de argumentación jurídica por instancias distintas de él mismo, de carácter científico-jurídico, y ello sólo es posible si dicho parámetro posee una naturaleza jurídico-positiva, nunca si posee una naturaleza suprapositiva. En este último supuesto, el Tribunal se convertiría en el único y último intérprete de una realidad objetiva, cuyo conocimiento subjetivo quedaría constitutivamente en sus manos, esto es, se convertiría en un auténtico poder constituyente — de naturaleza política y supraestatal — y dejaría de ser un poder constituido, pues él mismo habría de negar toda posibilidad de conocimiento jurídico subjetivo de dicho parámetro normativo de naturaleza objetiva (suprapositiva) y, por tanto, toda posibilidad de enjuiciamiento científico-jurídico de sus decisiones. Afirmar dicha suprapositividad y al mismo tiempo que el sujeto que la afirma conserve su naturaleza de poder público (jurisdiccional) es incluso incompatible con la naturaleza y función del derecho natural iusracionalista de la ilustración, que parece estar en la raíz de la suprapositividad del contenido de la cláusula de intangibilidad del Art. 79.III GG, pues precisamente la intención del dogma ilustrado iusnaturalista era la de que ningún poder público $-\mathrm{y}$ sólo el individuo como miembro de la sociedad- pudiese apelar al derecho suprapositivo ${ }^{108}$, lo que curiosamente solo sucede si los poderes públicos están sometidos únicamente al derecho positivo.

\section{CONCLUSIÓN: NECESARIOS PERO DEFECTUOSOS INTENTOS DE LA JURISDICCIÓN CONSTITUCIONAL NACIONAL PARA GARANTIZAR LA SUPREMACÍA CONSTITUCIONAL EN EL PROCESO DE INTEGRACIÓN EUROPEA}

El proceso de integración europea genera — sobre todo desde su aceleración con la creación de la Unión Europea en 1992 - una inevitable y enorme tensión entre Política y De-

107 Solo así se puede explicar que el BVerfG deje abierta la posibilidad de que la cláusula de intangibilidad del Art. 79.III GG pudiera vincular incluso al poder constituyente originario mencionado en el Art. 146 GG (BVerfGE, 123, 267, 343)

108 Cfr. MAUS, I., Naturrecht, Menschenrecht und politische Gerechtigkeit. Der Kommentar, Dialektik. Enzyklopädische Zeitschrift für Philosophie und Wissenschaften, n 1, 1994, pág. 13. 
recho. Concretamente entre las decisiones políticas necesarias para avanzar en el proceso de integración, que no son incardinables o no se quiere incardinar formalizadamente en los procesos jurídicos de creación de derecho primario de la Unión, y las Constituciones de los Estados miembros. Esta tensión creciente entre Política y Derecho aumenta por dos razones: en primer lugar, la falta de reconocimiento de la Unión Europea como un ordenamiento jurídico soberano que, poseyendo la competencia sobre las competencias, regule de forma autónoma la conducta de los Estados miembros como actores políticos del proceso de construcción de un futuro Estado Federal Europeo; y en segundo lugar, porque este proceso está dotado de un fuerte componente gubernamental (dado que es liderado por el Consejo europeo), lo que se opone a la mayoritaria configuración parlamentaria de las estructuras democráticas constitucionalmente previstas en los Estados miembros.

Allí donde los procesos de decisión juridificados se imponen sobre las pretensiones políticas, es decir, donde el medio prevalece sobre el fin, se relaja la tensión. En este sentido, la jurisprudencia del BVerfG sobre el proceso de integración europea es la expresión de la tensión existente entre el desarrollo de unas determinadas políticas, que se deciden sobre todo intergubernamentalmente a nivel comunitario, y la existencia de un marco jurídico constitucional nacional, que muchos Tribunales constitucionales de los Estados miembros siguen reconociendo como delimitador de lo políticamente posible, y del cual ellos se convierten en garantes (una faceta de la competencia sobre las competencias), al menos mientras el poder constituyente (constituido) democráticamente ejercido no disponga su transferencia a las instituciones europeas. Si las decisiones de política comunitaria solo fuesen delimitables en el marco del derecho de la Unión Europea, y controlables por su órgano jurisdiccional supremo, el Tribunal de Justicia, o si, alternativamente, todas esas decisiones, sea cual sea su rango, tuviesen en el plano constitucional interno de todos y cada uno de los Estados miembros el rango de una reforma constitucional ilimitada o incluso un valor normativo superior, esta tensión tendría un contexto radicalmente diferente y las decisiones de los Tribunales Constitucionales perderían mucha de su relevancia.

Se podrá decir que este planteamiento está impregnado de una visión estatal de la soberanía, que no se corresponde con la realidad política y jurídica del constitucionalismo multinivel que opera hoy en día en la Unión Europea. Admito que ello sea así en la medida en que no creo posible concebir epistemológicamente el sistema jurídico moderno si no es desde la perspectiva del monismo ordinamental con primacía de la Constitución nacional. Pero la concepción de la soberanía como una cualidad del ordenamiento jurídico, sea cual sea su ámbito territorial de vigencia, y su vinculación a la autonomía para decidir sobre las competencias y para controlar la transferencia y ejercicio de dichas competencias, no responde en absoluto a una visión estatalista y tradicional de la soberanía, sino a un concepto jurídico abstracto de la misma. Además, el pluralismo ordinamental como punto de partida epistemológico no sirve para dar una solución jurídicamente congruente y unitaria a la tensión referida y la única solución que aporta es la de someter la validez del ordenamiento (tanto del de la Unión Europea como del estatal) al imperio de la coacción política y económica imperante en un mundo económica pero no jurídicamente globalizado, lo que merma la legitimidad del sistema jurídico como subsistema social funcionalmente diferenciado.

Por ello, la posición de guardián que asume el BVerfG, aunque en ocasiones incurra en defectos jurídico-argumentativos, tiene especial valor en la medida en que esa misma 
influencia de factores económicos y políticos externos hace difícil que, ya desde una perspectiva monista con primacía del ordenamiento estatal, el proceso de construcción de un Estado federal europeo discurra sobre la base de una jurídica y ordenada disolución de la estatalidad de los Estados miembros y un consciente ejercicio democrático por parte de estos del poder constituyente-constituido, como ponen de relieve los actuales momentos de crisis política y económica de la Unión Europea. Es muy probable que la transformación de la Unión Europea en un Estado federal tenga lugar mediante un proceso constituyente en el que se ejerza un poder constituyente originario de carácter fáctico y sólo limitadamente democratizado, en el que, debido a la intensa participación de los Gobiernos de los Estados miembros (mucho más que los Parlamentos), las instituciones comunitarias o los mismos agentes económicos interesados en esa federalización de Europa, solo los Tribunales Constitucionales de los Estados miembros puedan introducir, mediante el control de constitucionalidad interno de los pasos dados, la exigida democratización y parlamentarización de ese proceso constituyente, y por eso tiene especial valor la jurisprudencia del BVerfG ${ }^{109}$.

***

TITLE: State's sovereignty, constitution's supremacy and european integration throughout the case law of the German Federal Constitutional Court

ABSTRACT: The article deals from a legal formalism perspective with the concepts of sovereignty, legal supremacy and constitutional democratic identity throughout the analysis of the most recent case-law of the German Federal Constitutional Court on the constitutional review of the european integration process. The conflicts that may arise between the Member State's Constitutions and the European Union Law show the existing tension between european integration politics and national constitutional law regarding the implementation of the constitutional substantive limitations to the european integration process. This tension can only be relaxed by interpreting the legal system's validity as a whole from a monist point of view that helps keeping its achieved functional differenciation and that still requires to place supremacy, and therefore the so called competence-competence power, within the national Member State's Constitution that grants a constituent power to stop or undo the States's participation in the European Intergration and a constitutional review power to review this process form the point of view of its constitutional limitations.

RESUMEN: A través del análisis de la más reciente jurisprudencia del Bundesverfassungsgericht sobre el control de constitucionalidad del proceso de integración europea, se revisan, desde una perspectiva formalista y estrictamente jurídica, los conceptos de soberanía, supremacía e identidad democrática constitucional, que aparecen habitualmente comprometidos en los conflictos entre la Constitución nacional y el derecho de la Unión Europea. Estos conflictos ponen de relieve una tensión entre pretensiones políticas de avance en el proceso de integración y límites jurídicos, que solo se puede resolver satisfactoriamente para mantener la diferenciación funcional alcanzada por el Derecho desde la perspectiva de una concepción monista de la validez del sistema juridico como un todo, en el que aún hay que ubicar la supremacía y, por tanto, la competencia sobre las competencias, en la Constitución nacional, en cuya disposición quedan tanto el poder constituyente como el poder de control de constitucionalidad.

PALABRAS ClAVE: soberanía, supremacía constitucional, integración europea, derecho comparado, primacía del derecho de la Unión Europea, teoría del Estado, teoría del derecho, teoría de la constitución, jurisdicción constitucional

KEYWORDS: sovereignty, constitution's supremacy, european integration, comparative law, EU's Law primacy, state's theory, theory of law, constitutional theory, constitutional review

FECHA DE RECEPCIÓN: 27.06.2012. FeCHA DE ACEPTACIÓN: 19.07.2012

109 Cfr. CAMISÓN YAGÜE, J. A., La sentencia del Bundesverfassungsgericht sobre el Tratado de Lisboa como «hoja de ruta constituyente» de la Unión Europea, Revista Universitaria Europea, n 14, 2011, págs. 98 ss.

UNED. Teoría y Realidad Constitucional, núm. 30, 2012, pp. 359-385. 